\title{
Impact of Timanian thrust systems on the late Neoproterozoic- Phanerozoic tectonic evolution of the Barents Sea and Svalbard
}

\author{
Jean-Baptiste P. Koehl ${ }^{1,2,3,4}$, Craig Magee ${ }^{5}$, and Ingrid M. Anell ${ }^{6}$ \\ ${ }^{1}$ Centre for Earth Evolution and Dynamics (CEED), University of Oslo, P.O. Box 1028 Blindern, 0315 Oslo, Norway \\ ${ }^{2}$ Department of Geosciences, UiT The Arctic University of Norway in Troms $\varnothing, 9037$ Troms $\varnothing$, Norway \\ ${ }^{3}$ Research Centre for Arctic Petroleum Exploration (ARCEx), UiT The Arctic University of Norway in Troms $\varnothing$, \\ 9037 Troms $\varnothing$, Norway \\ ${ }^{4}$ CAGE - Centre for Arctic Gas Hydrate, Environment and Climate, UiT The Arctic University of Norway in Troms $\emptyset$, \\ 9037 Troms $\varnothing$, Norway \\ ${ }^{5}$ School of Earth Science and Environment, University of Leeds, Leeds, LS2 9JT, UK \\ ${ }^{6}$ Department of Geosciences, University of Oslo, P.O. Box 1047 Blindern, 0316 Oslo, Norway
}

Correspondence: Jean-Baptiste P. Koehl (jean-baptiste.koehl@uit.no)

Received: 20 May 2021 - Discussion started: 27 May 2021

Revised: 12 November 2021 - Accepted: 19 November 2021 - Published: 12 January 2022

\begin{abstract}
The Svalbard Archipelago consists of three basement terranes that record a complex NeoproterozoicPhanerozoic tectonic history, including four contractional events (Grenvillian, Caledonian, Ellesmerian, and Eurekan) and two episodes of collapse- to rift-related extension (Devonian-Carboniferous and late Cenozoic). Previous studies suggest that these three terranes likely accreted during the early to mid-Paleozoic Caledonian and Ellesmerian orogenies. Yet recent geochronological analyses show that the northwestern and southwestern terranes of Svalbard both record an episode of amphibolite (-eclogite) facies metamorphism in the latest Neoproterozoic, which may relate to the 650-550 Ma Timanian Orogeny identified in northwestern Russia, northern Norway, and the Russian Barents Sea. However, discrete Timanian structures have yet to be identified in Svalbard and the Norwegian Barents Sea. Through analysis of seismic reflection, as well as regional gravimetric and magnetic data, this study demonstrates the presence of continuous thrust systems that are several kilometers thick, NNE-dipping, deeply buried, and extend thousands of kilometers from northwestern Russia to northeastern Norway, the northern Norwegian Barents Sea, and the Svalbard Archipelago. The consistency in orientation and geometry, as well as apparent linkage between these thrust systems and those recognized as part of the Timanian Orogeny in northwestern Russia and Novaya Zemlya,
\end{abstract}

suggests that the mapped structures are likely Timanian. If correct, these findings would imply that Svalbard's three basement terranes and the Barents Sea were accreted onto northern Norway during the Timanian Orogeny and should hence be attached to Baltica and northwestern Russia in future Neoproterozoic-early Paleozoic plate tectonics reconstructions. In the Phanerozoic, the study suggests that the interpreted Timanian thrust systems represent major preexisting zones of weakness that were reactivated, folded, and overprinted by (i.e., controlled the formation of new) brittle faults during later tectonic events. These faults are still active at present and can be linked to folding and offset of the seafloor.

\section{Introduction}

Recognizing and linking tectonic events across different terranes are critical to plate reconstructions. In the latest Neoproterozoic (at ca. 650-550 Ma), portions of northwestern Russia (e.g., Timan Range and Novaya Zemlya) and the Russian Barents Sea were accreted to northern Baltica by topSSW thrusting during the Timanian Orogeny (Olovyanishnikov et al., 2000; Kostyuchenko et al., 2006). Discrete Timanian structures with characteristic WNW-ESE strikes are sub-orthogonal to the $\mathrm{N}-\mathrm{S}$-trending Caledonian grain formed 
during the closure of the Iapetus Ocean (Gee et al., 1994; Witt-Nilsson et al., 1998; Johansson et al., 2004, 2005). Thus far, Timanian structures have only been identified in onshore-nearshore areas of northwestern Russia and northeastern Norway as well as offshore in the Russian Barents Sea and southeasternmost Norwegian Barents Sea (Barrère et al., 2009, 2011; Marello et al., 2010; Gernigon et al., 2018; Hassaan et al., 2020a, b, 2021; Hassaan, 2021). Therefore, the nature of basement rocks in the northern and southwestern Norwegian Barents Sea remains debatable. Some studies suggest a NE-SW-trending Caledonian suture within the Barents Sea (Gudlaugsson et al., 1998; Gee and Teben'kov, 2004; Breivik et al., 2005; Gee et al., 2008; Knudsen et al., 2019), whereas others argue for a swing into a N-S trend and merging of Norway and Svalbard's Caledonides, which probably continue into northern Greenland (Ziegler, 1988; Gernigon and Brönner, 2012; Gernigon et al., 2014). Regardless, these models solely relate basement structures in the northern and southwestern Norwegian Barents Sea to the Caledonian Orogeny, implying that Laurentia and Svalbard were not involved in the Timanian Orogeny and were separated from Baltica by the Iapetus Ocean in the latest Neoproterozoic (Torsvik and Trench, 1991; Cawood et al., 2001; Cocks and Torsvik, 2005; Torsvik et al., 2010; Merdith et al., 2021).

Nonetheless, geochronological data yielding Timanian ages suggest that deformation and metamorphism contemporaneous to the Timanian Orogeny affected parts of the Svalbard Archipelago, Laurentia, and possibly all Arctic regions (Estrada et al., 2018; Fig. 1a): (1) eclogite facies metamorphism (620-540 Ma; Peucat et al., 1989; Dallmeyer et al., 1990b) and eclogite facies xenoliths of mafic-intermediate granulite in Quaternary volcanic rocks are found in northern Spitsbergen (648-556 Ma; Griffin et al., 2012); (2) amphibolite facies metamorphism $(643 \pm 9 \mathrm{Ma}$; Majka et al., 2008, 2012, 2014; Mazur et al., 2009) and WNW-ESEstriking shear zones like the Vimsodden-Kosibapasset Shear Zone (VKSZ; Fig. 1b and c) occur in southwestern Spitsbergen (600-537 Ma; Manecki et al., 1998; Faehnrich et al., 2020); and (3) xenoliths of the subduction-related Midtkap igneous suite in northern Greenland yield Timanian ages (628-570 Ma; Rosa et al., 2016; Estrada et al., 2018). In addition, several recent studies also show the presence of NWSE- to E-W-trending basement grain in the Norwegian Barents Sea, which could possibly represent Timanian fabrics and structures (Fig. 1b; Barrère et al., 2009, 2011; Marello et al., 2010; Klitzke et al., 2019). Following these developments, a few paleo-plate reconstructions now place Svalbard together with Baltica in the latest Neoproterozoic-Paleozoic (e.g., Vernikovsky et al., 2011) and imply that the Norwegian Barents Sea and Svalbard basement may contain Timanian structures overprinted during later (e.g., Caledonian) deformation events.

To test the origin of basement grain in the northern Norwegian Barents Sea and Svalbard, the present study focuses on structures several kilometers deep identified on 2D seismic reflection data and correlated using regional gravimetric and magnetic data. These newly identified structures trend WNW-ESE, i.e., parallel to the Timanian structural grain in northwestern Russia and northern Norway (Fig. 1a-c). The structures are described and interpreted based on their geometry and potential kinematic indicators, and they are compared to well-known examples of Caledonian and $\mathrm{Ti}$ manian fabrics and structures elsewhere, e.g., onshore Norway (e.g., NNE-dipping Trollfjorden-Komagelva Fault Zone - TKFZ; Siedlecka and Siedlecki, 1967; Siedlecka, 1975), in Svalbard (e.g., gently north-plunging Atomfjella Antiform AA; Witt-Nilsson et al., 1998), northwestern Russia (NNEdipping Central Timan Fault - CTF - and related Mikulkin Antiform; Siedlecka and Roberts, 1995; Olovyanishnikov et al., 2000; Lorenz et al., 2004; Kostyuchenko et al., 2006), the southern Norwegian Barents Sea (Barrère et al., 2011; Gernigon et al., 2014), and the Russian Barents Sea (NNEdipping Baidaratsky fault zone - BaFZ; Lopatin et al., 2001; Korago et al., 2004; Fig. 1b and c). The present contribution proposes a scenario involving several episodes of deformation starting in the Timanian Orogeny and involving reactivation and overprinting of Timanian structures during the Caledonian Orogeny, Devonian-Carboniferous extension, Triassic extension, Eurekan tectonism, and present-day tectonism. Having established that Timanian structure may be present across the Barents Sea and Svalbard, we briefly discuss the potential implications for the tectonic evolution of the Barents Sea, the Svalbard Archipelago, and associated basins (e.g., Ora and Olga basins; Anell et al., 2016).

Should our interpretation of discrete Timanian structures throughout the Norwegian Barents Sea and Svalbard be validated by future research, it would support accretion of these terranes to Baltica in the late Neoproterozoic and place the Caledonian suture farther west than is commonly suggested (e.g., Breivik et al., 2005; Gernigon et al., 2014), thus leading to a major revision of plate tectonics models. In addition, constraining the extent and reactivation history of such faults may shed some light on their influence on younger tectonic events, such as Caledonian, Ellesmerian and Eurekan contraction, Devonian-Carboniferous collapse-rifting, and late Cenozoic breakup and ongoing extension.

\section{Geological setting}

\subsection{Timanian Orogeny}

The Timanian Orogeny corresponds to a ca. 650-550 Ma episode of NNE-SSW contractional deformation that affected northwestern Russia and northeastern Norway. During this tectonic episode, crustal-scale, WNW-ESE-striking, NNE-dipping thrust systems with a south-southwestwards transport direction (top-SSW; Siedlecka and Siedlecki, 1967; Siedlecka, 1975; Fig. 1b) accreted portions of the Rus- 


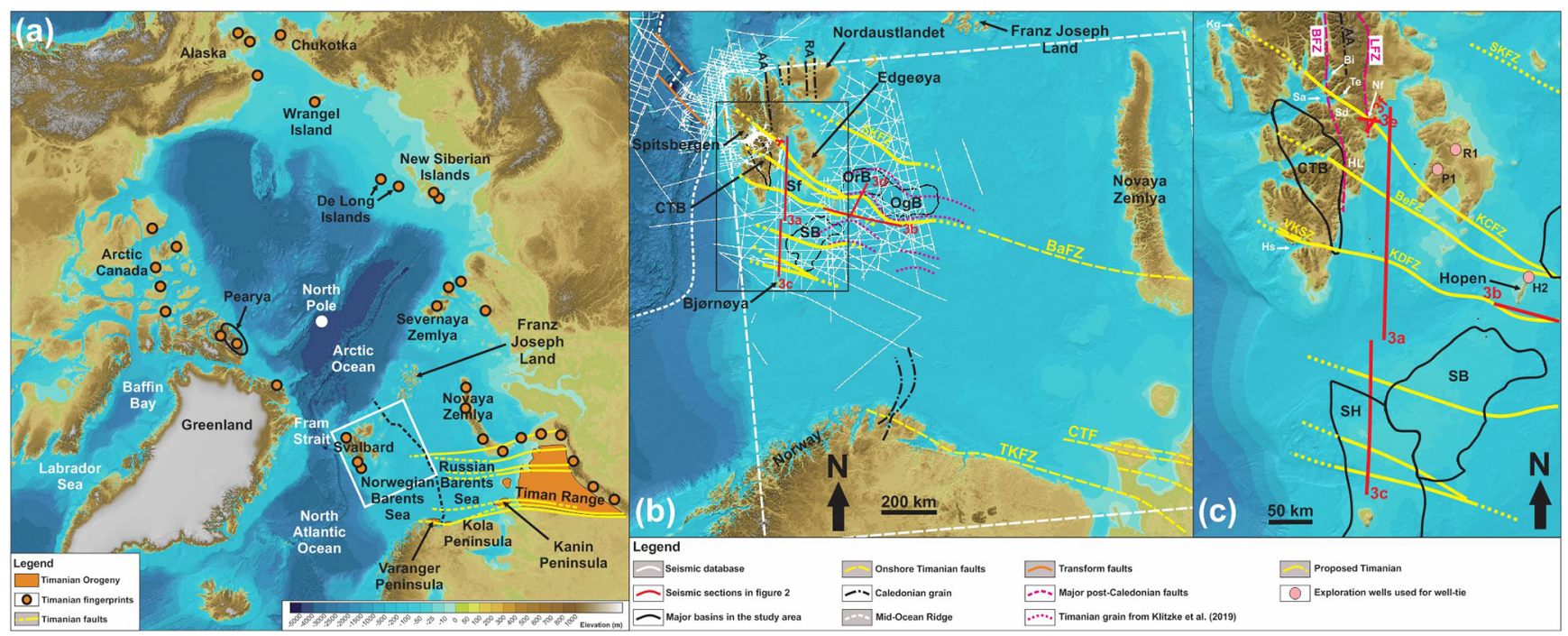

Figure 1. (a) Overview map showing the Timanian belt in Russia and Norway, as well as occurrences of Timanian fingerprints throughout the Arctic. (b) Regional map of Svalbard and the Barents Sea with the main geological elements and the seismic database used in the present study. The location of (b) is shown as a white frame in (a). (c) Zoomed-in view of the northern Norwegian Barents Sea and Svalbard showing the main faults and basins in the study area, as well as the proposed Timanian structures. The location of (c) is shown as a black frame in (b). The location of the Raddedalen-1 well is from Smyrak-Sikora et al. (2020). Topography and bathymetry are from Jakobsson et al. (2012). Abbreviations are as follows. AA: Atomfjella Antiform; BaFZ: Baidaratsky fault zone; BeFZ: Bellsundbanken fault zone; BFZ: Billefjorden fault zone; Bi: Billefjorden; CTB: Central Tertiary Basin; HL: Heer Land; Hs: Hornsund; H2: Hopen-2; KCFZ: Kongsfjorden-Cowanodden fault zone; KDFZ: Kinnhøgda-Daudbjørnpynten fault zone; Kg: Kongsfjorden; LFZ: Lomfjorden fault zone; Nf: Nordmannsfonna; OgB: Olga Basin; OrB: Ora Basin; P1: Plurdalen-1; RA: Rijpdalen Anticline; R1: Raddedalen-1; Sa: Sassenfjorden; SB: Sørkapp Basin; Sf: Storfjorden; SH: Stappen High; SKFZ: Steiløya-Krylen fault zone; Te: Tempelfjorden; TKFZ: Trollfjorden-Komagelva Fault Zone; VKSZ: Vimsodden-Kosibapasset Shear Zone.

sian Barents Sea and northwestern Russia onto northeastern Baltica, including Novaya Zemlya, Severnaya Zemlya, the Kanin Peninsula, the Timan Range, the Kola Peninsula (Siedlecka and Roberts, 1995; Olovyanishshnikov et al., 2000; Roberts and Siedlecka, 2002; Gee and Pease, 2004; Kostyuchenko et al., 2006; Lorenz et al., 2008; Marello et al., 2013), and the Varanger Peninsula in northeastern Norway (Siedlecka and Siedlecki, 1967; Siedlecka, 1975; Roberts and Olovyanishshnikov, 2004; Herrevold et al., 2009; Drachev, 2016; Fig. 1a). Major Timanian thrusts include the NNE-dipping Baidaratsky fault zone in the Russian Barents Sea and Novaya Zemlya (Fig. 1a and b; Eldholm and Ewing, 1971, their Fig. 4 profile C-D; Lopatin et al., 2001; Korago et al., 2004; Drachev, 2016), the NNE-dipping Central Timan Fault (and associated thrust anticline, the Mikulkin Antiform) on the Kanin Peninsula and the Timan Range (Siedlecka and Roberts, 1995; Olovyanishnikov et al., 2000; Lorenz et al., 2004; Kostyuchenko et al., 2006), and the NNE-dipping Trollfjorden-Komagelva Fault Zone in northern Norway (Siedlecka and Siedlecki, 1967; Siedlecka, 1975; Herrevold et al., 2009).

\subsection{Accretion of Svalbard basement terranes in the early Paleozoic}

The Svalbard Archipelago consists of three Precambrian basement terranes (Fig. 2), some of which show affinities with Greenland (northwestern and northeastern terranes), whereas others are possibly derived from Pearya (southwestern terrane; Harland and Wright, 1979; Ohta et al., 1989; Gee and Teben'kov, 2004; Labrousse et al., 2008; Piepjohn et al., 2013; Fortey and Bruton, 2013). These terranes possibly accreted during the mid-Paleozoic Caledonian (collision of Greenland with Svalbard and Norway at ca. 460$410 \mathrm{Ma}$; Horsfield, 1972; Dallmeyer et al., 1990a; Johansson et al., 2004, 2005; Faehnrich et al., 2020) and late Devonian Ellesmerian orogenies (Piepjohn, 2000; Majka and Kosminska, 2017). In these models, accretion was facilitated via hundreds of kilometers of displacement along (arcuate) N-S-striking strike-slip faults, such as the Billefjorden fault zone (BFZ - Harland, 1969; Harland et al., 1992; Labrousse et al., 2008) and the Lomfjorden fault zone (LFZ - Piepjohn et al., 2019; Fig. 2), although other studies suggest more limited strike-slip displacement (Lamar et al., 1986; Manby and Lyberis, 1992; Manby et al., 1994; Lamar and Douglass, 1995). Some previous researchers assumed that these large (strike-slip?) faults extended thousands of 
kilometers southwards and represented the continuation of Caledonian faults in Scotland (Norton et al., 1987; Dewey and Strachan, 2003). Caledonian contraction resulted in the formation of large fold-and-thrust complexes, such as the $\mathrm{N}-\mathrm{S}$-trending, gently north-plunging Atomfjella Antiform in northeastern Spitsbergen (Gee et al., 1994; Witt-Nilsson et al., 1998) and the N-S-trending Rijpdalen Anticline in Nordaustlandet (Johansson et al., 2004, 2005; Dumais and Brönner, 2020), whereas Ellesmerian tectonism may have formed narrow $\mathrm{N}-\mathrm{S}$-trending fold-and-thrust belts, like the Dickson Land and Germaniahalvøya fold-thrust zones (McCann, 2000; Piepjohn, 2000; Dallmann and Piepjohn, 2020).

In northern Norway, Timanian thrusts were reactivatedoverprinted in subsequent tectonic events (e.g., Caledonian Orogeny and late-post-Caledonian collapse-rifting) as dominantly strike- to oblique-slip faults (Siedlecka and Siedlecki, 1971; Roberts et al., 1991; Herrevold et al., 2009; Rice, 2014). A notable example is the folding and reactivation of Timanian fabrics and structures (e.g., NNE-dipping Trollfjorden-Komagelva Fault Zone) during the Caledonian Orogeny (Siedlecka and Siedlecki, 1971; Herrevold et al., 2009) and intrusion of Mississippian dolerite dikes along steeply dipping WNW-ESE-striking brittle faults that overprint the Trollfjorden-Komagelva Fault Zone in onshorenearshore northern Norway (Roberts et al., 1991; Lippard and Prestvik, 1997; Nasuti et al., 2015; Koehl et al., 2019).

\subsection{Late Paleozoic post-Caledonian collapse and rifting}

In the latest Silurian-Devonian, extensional collapse of the Caledonides led to the deposition of sedimentary basins several kilometers thick such as the Devonian Graben in northern Spitsbergen (Gee and Moody-Stuart, 1966; Friend et al., 1966; Friend and Moody-Stuart, 1972; Murascov and Mokin, 1979; Manby and Lyberis, 1992; Manby et al., 1994; Friend et al., 1997; McCann, 2000; Dallmann and Piepjohn, 2020). In places, $\mathrm{N}-\mathrm{S}$-trending basement ridges potentially exhumed as metamorphic core complexes along bowed, reactivated detachments, such as the Keisarhjelmen Detachment in northwestern Spitsbergen (Braathen et al., 2018).

In the latest Devonian-Mississippian, coal-rich sedimentary strata of the Billefjorden Group were deposited within normal fault-bounded basins throughout Spitsbergen (Cutbill and Challinor, 1965; Harland et al., 1974; Cutbill et al., 1976; Aakvik, 1981; Koehl and Muñoz-Barrera, 2018; Koehl, 2021) and the Norwegian Barents Sea (Koehl et al., 2018; Tonstad, 2018). As rift-related normal faulting evolved, Pennsylvanian sedimentation was localized into a few NS-trending basins that are several kilometers deep, like the Billefjorden Trough (Cutbill and Challinor, 1965; Braathen et al., 2011; Koehl et al., 2021) and the E-W-trending Ora Basin (Anell et al., 2016). In the Permian, rift-related faulting stopped and platform carbonates were deposited throughout Svalbard (Cutbill and Challinor, 1965) and the Barents Sea (Larssen et al., 2005).
Overall, the several-kilometers-thick late Paleozoic sedimentary succession deposited during late-post-Caledonian extension buried Proterozoic basement rocks. As a result, these rocks are sparsely exposed and thus difficult to study.

\subsection{Mesozoic sedimentation and magmatism}

In the Mesozoic, Svalbard and the Barents Sea remained tectonically quiet and were only affected by minor Triassic normal faulting (e.g., Anell et al., 2013; Osmundsen et al., 2014; Ogata et al., 2018; Smyrak-Sikora et al., 2020). In the Early Cretaceous, Svalbard was affected by a regional episode of magmatism recorded by the intrusion of numerous dikes and sills of the Diabasodden Suite (Senger et al., 2013).

\subsection{Early Cenozoic Eurekan tectonism}

The opening of the Labrador Sea and Baffin Bay between Greenland and Arctic Canada in the early Cenozoic (Chalmers and Pulvercraft, 2001; Oakey and Chalmers, 2012) led to the collision of northern Greenland with Svalbard and the formation of a fold-and-thrust belt with topeast thrusts and east-verging folds in western Spitsbergen (Dallmann et al., 1993). In eastern Spitsbergen, this deformation event is characterized by dominantly thin-skinned deformation structures, including décollements, some of which show westward transport directions (Andresen et al., 1992; Haremo and Andresen, 1992). Notably, the N-S-striking Agardhbukta Fault, a major splay and/or segment of the N-Sstriking Lomfjorden fault zone, accommodated reverse and possibly strike-slip movements during this event (Piepjohn et al., 2019).

\subsection{Late Cenozoic opening of the Fram Strait}

After the end of extension in the Labrador Sea and Baffin Bay, the Fram Strait started to open in the earliest Oligocene (Engen et al., 2008). Tectonic extension and breakup in the Fram Strait resulted in the formation of two major NW-SEstriking transform faults (Lowell, 1972; Thiede et al., 1990; Fig. 1b).

\section{Methods and datasets}

Seismic surveys from the DISKOS database (see Fig. $1 \mathrm{~b}$ and c and Supplement S1 for location) were used to interpret basement-seated structures and related, younger, brittle overprints (Figs. 3a-f, 4a-h and Supplement S2). Other features of interest include potential dikes, which commonly appear as high positive reflections on seismic data. The geology interpreted from onshore seismic data was directly correlated with geological maps of the Norwegian Polar Institute (e.g., Dallmann, 2015). Where possible, interpretation of offshore seismic data was tied to onshore geological maps and to exploration wells Raddedalen-1 and Plurdalen-1 on Edgeøya 


\begin{tabular}{|c|c|c|c|c|c|}
\hline Era/Period/Epoch & \multicolumn{2}{|c|}{ Neoproterozoic } & \multicolumn{2}{|c|}{ Ordovician } & Silurian \\
\hline Time (Ma) & 650 & $550\}$ & 490 & 445 & 420 \\
\hline \multicolumn{6}{|l|}{ Current model } \\
\hline \multirow{2}{*}{ Legend } & & Paleozoic faults & $s$ & \multirow{2}{*}{\multicolumn{2}{|c|}{ Relative fault movements }} \\
\hline & 4 & Main tectonic stress & & & \\
\hline
\end{tabular}

Figure 2. Paleogeographic reconstruction of the Svalbard Archipelago in the latest Neoproterozoic during the Timanian Orogeny and in the early to mid-Paleozoic during the Caledonian Orogeny according to previous models (e.g., Harland, 1969; Labrousse et al., 2008).

(Bro and Shvarts, 1983; Harland and Kelly, 1997) as well as to the Hopen-2 well on Hopen (Anell et al., 2014; Fig. 1c and Supplement S3). The Raddedalen-1 well penetrated $2823 \mathrm{~m}$ of upper Permian to Mississippian or Ordovician strata, the Plurdalen well $2351 \mathrm{~m}$ of Middle Triassic to (pre-?) Devonian strata, and the Hopen-2 well $2840 \mathrm{~m}$ of Middle-Upper Triassic to Pennsylvanian strata (Bro and Shvarts, 1983; Harland and Kelly, 1997; Anell et al., 2014; Senger et al., 2019). Note that the present contribution favors the interpretation of lower Paleozoic (Ordovician-Silurian) rocks in the Raddedalen-1 well by Bro and Shvarts (1983) to that of upper Paleozoic (Upper Devonian-Mississippian) by Cambridge Svalbard Exploration (see contrasting interpretations in Harland and Kelly, 1997). This is based on the more detailed lithological, palynological, and paleontological analyses by the former and on the strong contrast of the lithologies described in the well with Devonian-Mississippian successions on Svalbard (Cutbill and Challinor, 1965; Cutbill et al., 1976; Friend et al., 1997; Dallmann and Piepjohn, 2020).

The present contribution only includes a few examples of seismic sections. However, more interpreted and uninterpreted seismic data are available in the Supplement (S1 and S2) and from the Norwegian Petroleum Directorate (DISKOS database). None of the seismic sections were depth-converted, and thicknesses therefore appear in seconds (two-way time; TWT). However, local time conversion was performed to tie seismic wells in onshore Edgeøya to the seismic section in Storfjorden, and depth conversion was performed locally to evaluate fault displacement. Velocities of Gernigon et al. (2018) were used in these conversions. Supplement S3 includes further details related to these conversions.

The boundary between Precambrian, lower Paleozoic and upper Paleozoic successions offshore are interpreted as major unconformities that truncate underlying reflections and fold structures (e.g., Fig. 3a-c). The boundaries between Devonian-Permian and Mesozoic successions were tied to the Raddedalen-1, Plurdalen-1, and Hopen-2 exploration wells for offshore parts of the study area. The boundary between Devonian-Mississippian and Pennsylvanian-Permian onshore Svalbard are interpreted as a major unconformity truncating Devonian-Mississippian dikes (see Fig. 3e).

The correlation of kilometer-thick structures discussed in the present contribution was also tested using gravimetric and magnetic data in cross section (Fig. 3a-f) as well as regional magnetic and gravimetric data in the northern Norwegian Barents Sea and Svalbard (Fig. 5 and Supplement S4) from the Federal Institute for Geosciences and Natural Resources in Germany in map view (Klitzke et al., 2019). Regional gravimetric and magnetic data are also used to interpret deep basement fabrics and structures, e.g., regional folds (gravimetric highs commonly associated with major anticlines of thickened dense basement with highmetamorphic-grade, i.e., Precambrian, rocks - e.g., Mikulkin Antiform; Lorenz et al., 2004; Kostyuchenko et al., 2006 and gravimetric lows with synclines with less dense sedimentary basins) and large faults bounding magmatic complexes and/or intruded by magmatic bodies that commonly correlate with elongated gravimetric and/or magnetic anomalies (e.g., Kostyuchenko et al., 2006; Koehl et al., 2019), as well as to discuss the relationship of the described structures with known structural trends in onshore basement rocks in Russia, Norway, and Svalbard. Magnetic and gravimetric anomalies not related to Timanian and Caledonian grains will not be discussed in the present study. 


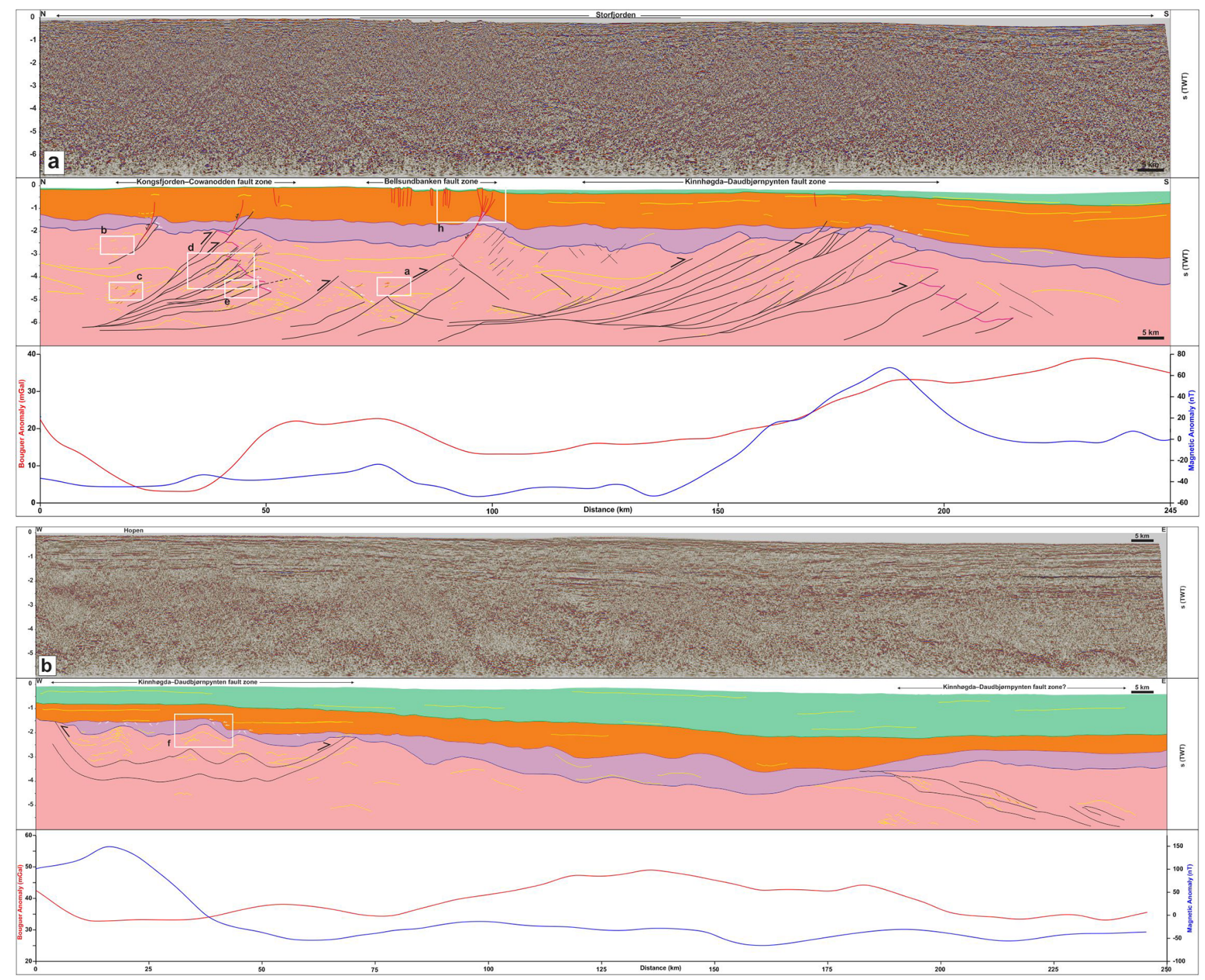

Figure 3.

\section{Results and interpretations}

First, the interpretation of seismic data is described by area, including (1) Storfjorden (between Edgeøya and Spitsbergen) and the northeastern part of the Norwegian Barents Sea (east of Edgeøya), (2) Nordmannsfonna to Sassenfjorden in the onshore-nearshore area of the eastern-central part of Spitsbergen, and (3) the northwestern part of the Norwegian Barents Sea between Bjørnøya and Spitsbergen (Fig. 1b and c). The description in each area starts with deep Precambrian basement rocks and shallow sedimentary rock units and ends with deep brittle-ductile structures and with shallow brittle faults. Then, potential field data and regional gravimetric and magnetic anomalies in the Barents Sea and Svalbard are described, compared, and correlated with seismic data as well as major Timanian and Caledonian fabrics and structures onshore in northwestern Russia, Svalbard, and Norway. Please see high-resolution versions of all the figures and the Supplement on DataverseNO (https://doi.org/10.18710/CE8RQH).

\subsection{Structures in the northwestern-northeastern Norwegian Barents Sea, Storfjorden, and central-eastern Spitsbergen}

\subsubsection{Storfjorden and northeastern Norwegian Barents Sea}

Folded Precambrian-lower Paleozoic basement rocks. Seismic facies at depths of 2-6s (TWT) typically comprise successions of laterally discontinuous $(<3 \mathrm{~km}$ long), subhorizontal, moderately curving-undulating, moderate-highamplitude seismic reflections that alternate with packages of highly disrupted and/or curved low-amplitude seismic reflections (see yellow lines within pink and purple units in 


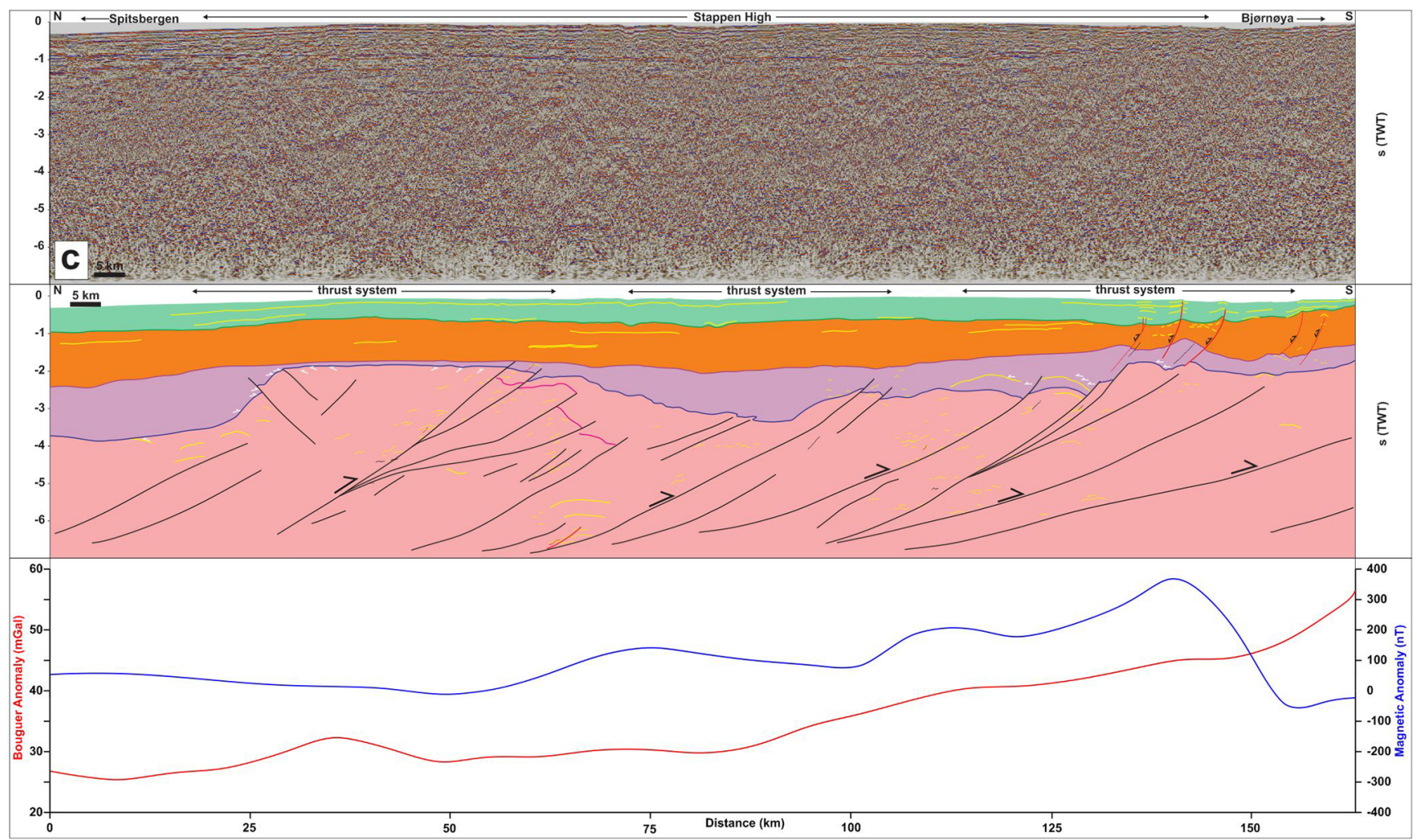

Figure 3.

Figs. 3a and 4a). The curving geometries of the moderate- to high-amplitude reflections display a typical wavelength with a scale of kilometers to hundreds of meters and are commonly asymmetric, seemingly leaning or verging towards the south to SSW (see yellow lines in Fig. 4b). Based on ties with well bores on Edgeøya (Raddedalen-1 well; Bro and Shvarts, 1983; Harland and Kelly, 1997), these asymmetric, undulate features most likely correspond to SSW-verging folds in Precambrian-lower Paleozoic basement rocks. In places, apparent reverse offsets of these undulate reflections align along moderately-gently north- to NNE-dipping surfaces (see red lines in Fig. 4a and c), which are therefore interpreted as minor, top-south to SSW, brittle thrusts.

Upper Paleozoic-Mesozoic sedimentary successions. In Storfjorden and the northwestern Norwegian Barents Sea, shallow (0-3 s TWT) seismic reflections above folded and thrust Precambrian-lower Paleozoic basement rocks show significantly more continuous patterns $(\gg 5 \mathrm{~km})$, gently curving-undulating geometries, and only local disruptions by shallow, dominantly NNE-dipping, high-angle listric disruptions (see yellow lines within orange unit in Fig. 3a and c). In the northeastern Barents Sea, these reflections are largely flat-lying (see yellow lines within orange unit in Fig. 3b and d). Based on field mapping campaigns and well bores in adjacent onshore areas of Spitsbergen, Edgeøya, Hopen, and Bjørnøya (see location in Fig. 1b), these continuous re- flections are interpreted as mildly folded upper PaleozoicMesozoic (-Cenozoic?) sedimentary strata (Dallmann and Krasil'scikov, 1996; Harland and Kelly, 1997; Worsley et al., 2001; Dallmann, 2015). The Permian-Triassic boundary was correlated throughout the northern Norwegian Barents Sea and Storfjorden by using the tie of Anell et al. (2014) to the Hopen-2 well.

Deep thrust systems. The packages of sub-horizontal, moderately curving-undulating (folded Precambrian-lower Paleozoic basement) reflections alternate laterally from north to south with $20-60 \mathrm{~km}$ wide, up to $4 \mathrm{~s}$ thick (TWT), upwards-thickening, wedge-shaped packages (areas with high concentrations of black lines in Fig. 3a and d). These wide upwards-thickening packages consist of two types of reflections. First, they include planar, continuous, gentlymoderately north- to NNE-dipping, sub-parallel, highamplitude reflections that commonly merge together downwards and that can be traced and correlated on several seismic sections in Storfjorden (black lines in Fig. 3a). Upwards, these reflections terminate against high-amplitude convexupwards reflections interpreted as intra- Precambrian-lower Paleozoic basement reflections (fuchsia lines in Fig. 3a and c) or continue as moderately NNE-dipping disruption surfaces that offset these intra-basement reflections top-SSW (e.g., offset intra-Precambrian unconformities in Figs. 3a and $c$ and $4 d)$. 

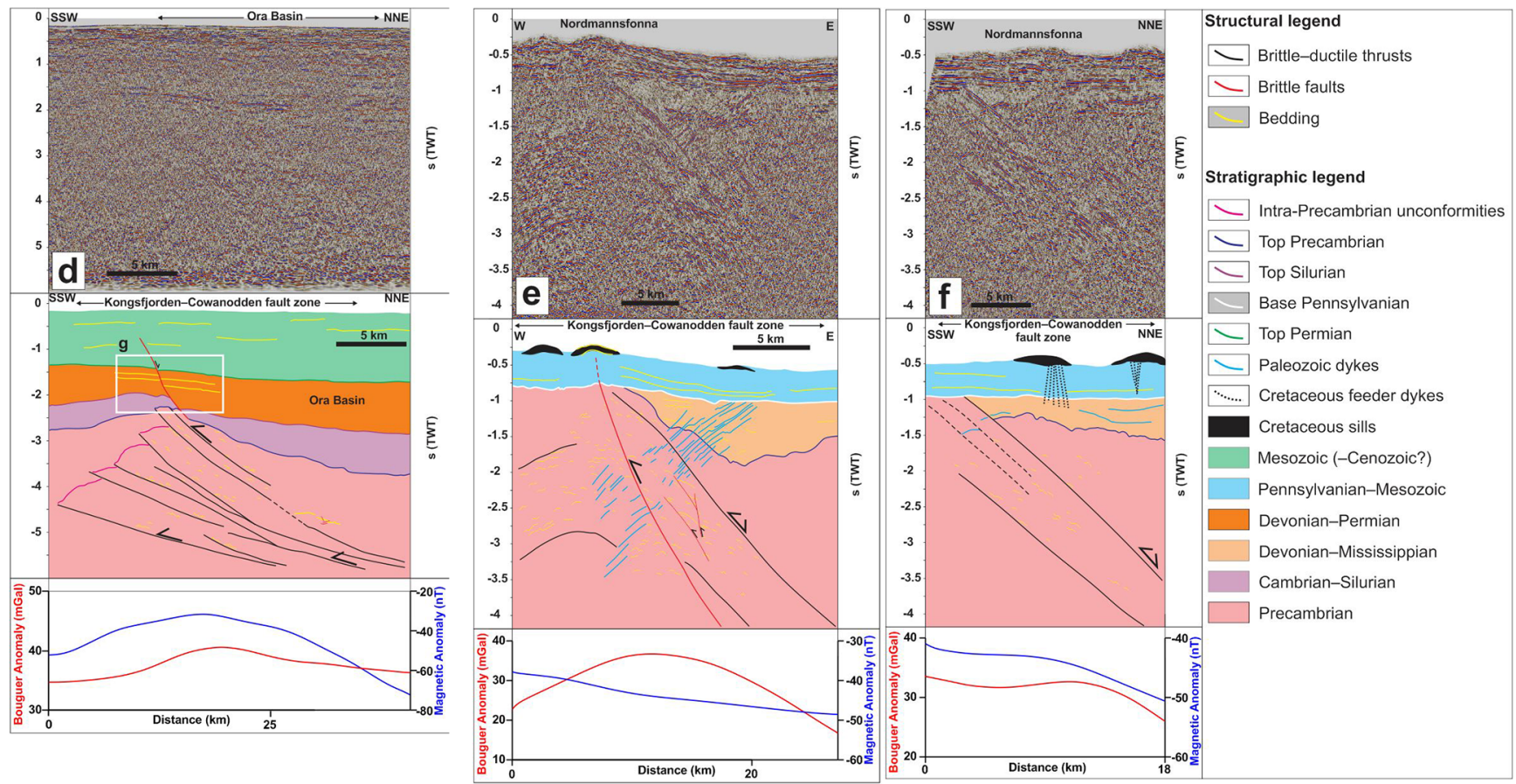

Figure 3. Interpreted seismic profiles and associated potential field data (a) in Storfjorden, (b) south of Hopen, (c) on the Stappen High in the northwestern Norwegian Barents Sea between Spitsbergen and Bjørnøya, (d) on the southern flank of the Ora Basin in the northeastern Norwegian Barents Sea, and (e and f) in Nordmannsfonna in eastern Spitsbergen. The seismic profiles show top-SSW Timanian thrusts that were reactivated and overprinted during subsequent tectonic events such as Caledonian contraction, Devonian-Carboniferous late-post Caledonian collapse and rifting, Eurekan contraction, and present-day contraction. Profiles (e) and (f) also show Paleozoic and Cretaceous intrusions. The white frames show the location of zoomed-in portions of the profiles displayed in Fig. 4. Potential field data below the seismic profiles include Bouguer anomalies (red lines) and magnetic anomalies (blue lines). The potential field data show consistently high gravimetric anomalies and partial correlation with high magnetism towards the footwall of each major thrust system (i.e., towards thickened portions of the crust).

Second, sub-parallel, high-amplitude reflections bound wedge-shaped, upwards-thickening packages of asymmetric, curved, south- to SSW-leaning, moderately north- to NNE-dipping, moderate-amplitude reflections showing narrow ( $<1 \mathrm{~km}$ wide) upwards-convex geometries (Fig. 4d). These asymmetric reflections also commonly appear as gently north- to NNE-dipping packages of Z-shaped reflections bounded by sub-parallel, planar, high-amplitude reflections (see yellow lines in Fig. 4e). Asymmetric, south- to SSW-leaning, convex-upwards reflections are interpreted as south- to SSW-verging fold anticlines reflecting relatively low amounts of plastic deformation of layered rocks.

The alternation of packages of layered rocks folded into SSW-verging folds (yellow lines in Fig. 3a-c) with packages of planar, NNE-dipping, sub-parallel, high-amplitude reflections (black lines in Fig. 3a-c) suggests that the latter reflection packages represent zones where initial layering was destroyed and/or possibly reoriented, i.e., areas that accommodated larger amounts of deformation and tectonic displacement. Thus, planar, gentlymoderately north- to NNE-dipping, high-amplitude reflections (black lines in Fig. 3a-c) are interpreted as low-angle brittle-ductile thrust systems. We name these thrust systems (from north to south) the Steiløya-Krylen (SKFZ), Kongsfjorden-Cowanodden (KCFZ), Bellsundbanken (BeFZ), and Kinnhøgda-Daudbjørnpynten fault zones (KDFZ; Fig. 3a and Supplement S2a and b; see Fig. 1c for location of the thrusts).

The relatively high-amplitude character of planar, NNEdipping reflections within the thrusts suggests that these tectonic structures consist of sub-parallel layers of rocks and minerals with significantly different physical properties. A probable explanation for such laterally continuous and consistently high-amplitude reflections is partial recrystallization of rock layers-mineral bands into rocks and minerals with significantly higher density along intra-thrust planes that accommodated large amounts of displacement (e.g., mylonitization; Fountain et al., 1984; Hurich et al., 1985). In places, packages of aggregates of Z-shaped reflections bounded upwards and downwards by individual low-angle thrust surfaces are interpreted as forward-dipping duplex structures (e.g., Boyer and Elliott, 1982) reflecting relatively strong plastic deformation between low-angle, brittle-ductile (mylonitic?) thrusts (see yellow lines in Fig. 4e). 


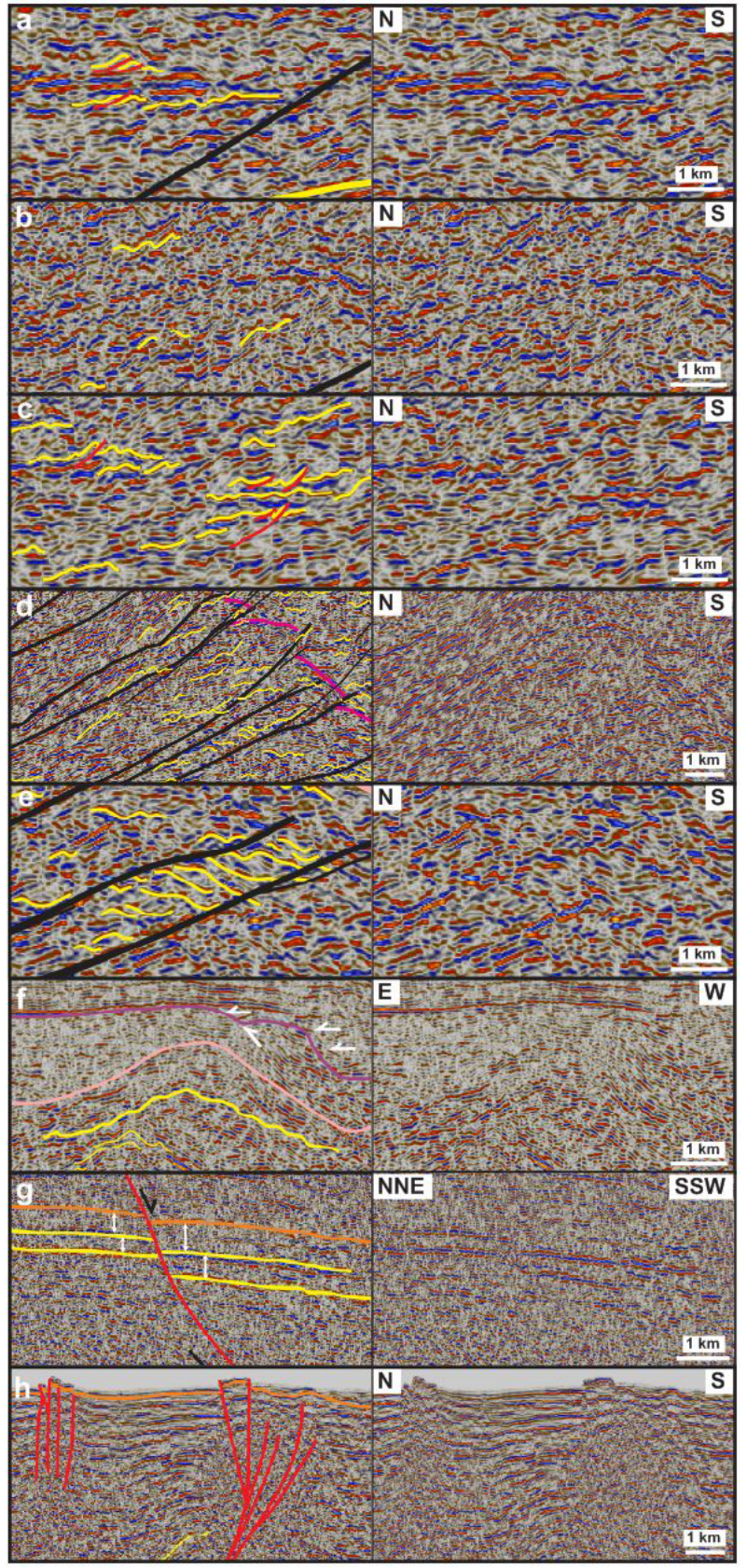

Figure 4. Zoomed-in views of the seismic profiles shown in Fig. 3 showing (a) upright fold structures, (b) SSW-verging folds, and (c) top-SSW minor thrusts in Precambrian-lower Paleozoic (meta)sedimentary basement rocks. (d) SSW-verging folds and NNE-dipping mylonitic shear zones within a major thrust that offsets major basement unconformities (fuchsia lines) top-SSW. (e) Duplex structures within a major top-SSW thrust and (f) a N-S- to NNE-SSW-trending, 5-15 km wide, symmetrical, upright macrofold with an associated scale of kilometers to hundreds of meters and parasitic macro- to meso-folds. (g) Syn-tectonic thickening in Devonian-Carboniferous (-Permian?) sedimentary strata offset down-NNE by a normal fault that merges with a thick mylonitic shear zone at depth. (h) Recent-ongoing reverse offsets of the seafloor reflection by multiple inverted, NNE-dipping normal faults in Storfjorden. See Fig. 3 for the location of each zoom and for the legend.

https://doi.org/10.5194/se-13-85-2022
The Kongsfjorden-Cowanodden, Bellsundbanken, and Kinnhøgda-Daudbjørnpynten fault zones can be traced eastsoutheast of Edgeøya as a similar series of $20-60 \mathrm{~km}$ wide, up to $4 \mathrm{~s}$ thick (TWT), upwards-thickening packages (e.g., black lines in Fig. 3d and Supplement S2a). However, their imaging along NNW-SSE-trending seismic sections is much more chaotic, and it is more difficult to identify smaller structures (like south-verging folds and minor thrusts) within each thrust system (e.g., Supplement S2a). This suggests that these three thrust systems strike oblique to NNWSSE-trending seismic sections (Supplement S2a), whereas they are most likely sub-orthogonal to N-S- to NNE-SSWtrending seismic sections in Storfjorden (Fig. 3a). The only orientation that reconciles these seismic facies variations (i.e., well-imaged on NNE-SSW-trending seismic sections and poorly imaged by NNW-SSE-trending seismic sections; Fig. 3a and Supplement S2a) is an overall WNW-ESE strike.

South of each $20-60 \mathrm{~km}$ wide package of thrust surfaces and related fold and duplex structures, seismic reflections representing Precambrian-lower Paleozoic basement rocks typically appear as gently curved, convex-upwards, relatively continuous reflections showing sub-horizontal seismic onlaps (see white arrows in Fig. 3a-f). This suggests that Precambrian-lower Paleozoic basement rocks most likely consist of (meta)sedimentary rocks (analogous to those observed in northeastern Spitsbergen and Nordaustlandet; Harland et al., 1993; Stouge et al., 2011) that were deposited in foreland and piggyback basins ahead of each $20-60 \mathrm{~km}$ wide package (Fig. 3a-f).

Hence, based on the upwards-thickening geometry of the packages of south- to SSW-verging folds and of forwarddipping duplexes, on the top-SSW reverse offsets of intrabasement reflections by low-angle brittle-ductile thrust surfaces, on the upwards truncation of these low-angle thrusts by intra-basement reflections, and on the onlapping geometries of (meta)sedimentary basement rocks south of each set of top-SSW thrust surfaces, the $20-60 \mathrm{~km}$ wide, upwards-thickening, wedge-shaped packages are interpreted as crustal-scale, several-kilometers-thick, north- to NNEdipping, top-SSW, brittle-ductile thrust systems (see fault zones with high concentration of black lines in Fig. 3a-f). These thrust systems include low-angle, brittle-ductile, mylonitic thrust surfaces (black lines in Fig. 4d and e) separating upwards-thickening thrust sheets that consist of gently to strongly folded basement rocks and forward-dipping duplex structures (yellow lines in Fig. 4d and e). These thrust sheets are interpreted to reflect accretion and stacking from the north or north-northeast. The interpreted thrust systems are comparable in seismic facies and thickness to kilometerthick mylonitic shear zones in the Norwegian North Sea (Phillips et al., 2016) and southwestern Norwegian Barents Sea (Koehl et al., 2018).

$N-S$-trending folds. On E-W seismic cross sections, reflections of the Kongsfjorden-Cowanodden, Bellsundbanken, and Kinnhøgda-Daudbjørnpynten fault zones de- 
fine large, $50-100 \mathrm{~km}$ wide, U-shaped, symmetrical depressions (black lines in Fig. 3b) on the edge of which they are truncated at a high angle and overlain by folded lower Paleozoic and mildly folded to flat-lying upper Paleozoic (meta)sedimentary rocks (purple and orange units with associated yellow lines in Fig. 3b). In addition, within these Ushaped depressions, the thrust systems show curving up and down as well as symmetrical geometries with $5-15 \mathrm{~km}$ wavelength (yellow lines within the pink unit in Figs. $3 \mathrm{~b}$ and $4 \mathrm{f}$ ). Also notice the undulating pattern with a scale of kilometers to hundreds of meters of 5-15 km wide curved geometries (yellow lines in Fig. 4f). Based on the truncation and abrupt upward disappearance of high-amplitude seismic reflections characterizing the thrust systems, the high-angle truncation of the thrusts is interpreted as a major erosional unconformity (dark blue line in Fig. $3 \mathrm{~b}$ and pink line in Fig. 4f) and the large U-shaped depressions as large N-S- to NNE-SSWtrending, upright regional folds (black lines in Fig. 3b). Furthermore, the 5-15 km wide, symmetrical, curved geometries and associated scales of kilometers to hundreds of meters, with an undulating pattern of seismic reflections within the thrusts, are interpreted as similarly (N-S- to NNE-SSW-) trending, upright, parasitic macro-scale to mesoscale folds (yellow lines in Figs. $3 \mathrm{~b}$ and $4 \mathrm{f}$ ).

Shallow brittle faults. In places, near the top of the 20-60 km wide thrust systems (Kongsfjorden-Cowanodden, Bellsundbanken, and Kinnhøgda-Daudbjørnpynten fault zones), low-angle brittle-ductile thrust surfaces merge upwards with high-angle to vertical, listric, north- to NNEdipping disruption surfaces at depths of ca. 2-3 s (TWT; see red lines in Fig. 3a and d). These listric disruption surfaces truncate shallow, laterally continuous reflections that display gently curved, symmetric geometries in Storfjorden (yellow lines in Fig. 3a) and flat-lying geometries in the northeastern Norwegian Barents Sea (yellow lines in Fig. 3d). Notably, they show minor, down-NNE normal offsets and related minor southwards thickening (towards the disruption) of seismic sub-units within Devonian-Carboniferous (-Permian?) sedimentary strata in the north in both Storfjorden and the northeastern Barents Sea (Fig. 3a-d and white double arrows in Fig. 4g). In addition, they display minor reverse offsets and associated gentle upright folding of shallow continuous reflections potentially representing upper Mesozoic (-Cenozoic?) sedimentary deposits in Storfjorden (Fig. 3a$\mathrm{c}$ and e, and orange lines in Fig. 4h). Note that flat-lying Mesozoic (-Cenozoic?) sedimentary rocks are not offset in the northeastern Norwegian Barents Sea (Fig. 3d).

Based on the observed normal offsets and southwardsthickening of Devonian-Carboniferous (-Permian?) sedimentary strata north of these disruption surfaces (e.g., white double arrows in Fig. 4g), these are interpreted as synsedimentary Devonian-Carboniferous normal faults. The minor reverse offsets and associated gentle upright folding of Mesozoic (-Cenozoic?) sedimentary rocks in Storfjorden (e.g., orange lines in Fig. 4h) suggest that these nor- mal faults were mildly inverted near Svalbard in the Cenozoic. However, it is unclear whether inversion in Storfjorden initiated in the early Cenozoic or later. Nonetheless, minor reverse offset and folding of the seafloor clearly indicate ongoing inversion along these faults (Figs. 3a and $\mathrm{c}$, and $4 \mathrm{~h}$ ). Furthermore, considering the merging relationship between these high-angle listric disruption surfaces and underlying shear zones (i.e., merging black and red lines in Fig. 3a and c, d), we propose that the formation of Devonian-Carboniferous normal faults was controlled by the crustal-scale, north- to NNE-dipping (inherited) thrust systems (Kongsfjorden-Cowanodden, Bellsundbanken, and Kinnhøgda-Daudbjørnpynten fault zones).

\subsubsection{Nordmannsfonna-Sassenfjorden (eastern-central Spitsbergen)}

Deep thrust system and $N-S$-trending folds. Seismic data from Nordmannsfonna to Sassenfjorden in eastern Spitsbergen (see Fig. 1c for location) show reflection packages including both planar, continuous, moderately dipping high-amplitude reflections and upwards-curving, moderateamplitude reflections (black and yellow lines in Fig. 3e and f). These two sets are similar to reflection packages interpreted as low-angle, brittle-ductile mylonitic thrusts bounding packages of south- to SSW-verging folds in Storfjorden and the northeastern Norwegian Barents Sea (black and yellow lines in Fig. 3a and d, and Supplement S2a). In addition, they are located at similar depths ( $>2 \mathrm{~s}$ TWT) and seem to align with the Kongsfjorden-Cowanodden fault zone in Storfjorden along a WNW-ESE-trending axis. Hence, we interpret the deep, continuous, high-amplitude reflections in eastern Spitsbergen as the western continuation of the top-SSW Kongsfjorden-Cowanodden fault zone. This thrust can be traced on seismic data as gently NNE-dipping, high-amplitude reflections in Sassendalen, SassenfjordenTempelfjorden (Supplement S2c-d), and possibly in Billefjorden (Koehl et al., 2021, their Fig. 9a and b).

In Nordmannsfonna, the base-Pennsylvanian unconformity (white line in Fig. 3e and f; tied to onshore geological maps; Dallmann, 2015) truncates the KongsfjordenCowanodden fault zone (black lines in Fig. 3e and f) upwards, and the fault shows pronounced variations in dip direction ranging from east-dipping in the east to NNE-dipping in the north and WNW-dipping in the west, which result in a ca. 15-20 km wide, north- to NNE-plunging dome-shaped and convex-upwards geometry (black lines in Fig. 3e and f). This portion of the thrust system is interpreted to be folded into a major NNE- to north-plunging upright fold, whose 3D geometry was accurately constrained due to good seismic coverage in this area (Fig. 1c).

Small-scale structures within the KongsfjordenCowanodden fault zone also show asymmetric folds and internal seismic units terminating upwards with convex-upwards reflections (yellow lines in Fig. 3e and f), 
suggesting top-SSW nappe thrusting in the northern portion of the thrust system. However, on E-W cross sections, seismic data reveal a set of west-verging folds in the east and a more chaotic pattern of symmetrical, dominantly upright folds in the west (yellow lines in Fig. 3e) below a major, high-angle, east-dipping disruption surface (thick red line in Fig. 3e) that crosscuts the Kongsfjorden-Cowanodden fault zone.

Shallow brittle faults. The high-angle, east-dipping disruption surface (thick red line in Fig. 3e) is associated with minor sub-vertical to steeply east-dipping disruption surfaces (thin red lines in Fig. 3e). This feature shows a major reverse, top-west offset ( $>0.5 \mathrm{~s}$ TWT) of seismic units and reflections at depth $>0.75 \mathrm{~s}$ (TWT; e.g., black lines in Fig. 3e), as well as minor reverse offset $(<0.1 \mathrm{~s}$ TWT) and upwardsconvex curving of adjacent reflections at depth $<0.75 \mathrm{~s}$ (TWT; white line and yellow lines within blue and units in Fig. 3e). Since the major disruption coincides with the location of the Agardhbukta Fault (Piepjohn et al., 2019; see Fig. 1 for location) and shows a steep inclination near the surface similar to that of the Agardhbukta Fault, it is interpreted as the subsurface expression of this fault. The Agardhbukta Fault offsets the Kongsfjorden-Cowanodden fault zone in a reverse fashion ( $>0.5 \mathrm{~s}$ TWT; black lines in Fig. 3e) and terminates upwards within and slightly offsets upper PaleozoicMesozoic sedimentary rocks (blue and black units and associated yellow lines in Fig. 3e), which were correlated with onshore outcrops in eastern Spitsbergen (Andresen et al., 1992; Haremo and Andresen, 1992; Dallmann, 2015). As a result, these rocks are folded into a N-S-trending, open, upright fold around the fault tip, both of which suggest top-west movements along the fault (Fig. 3e).

Pre-Pennsylvanian dikes. In the hanging wall and on the eastern flank of the folded Kongsfjorden-Cowanodden fault zone in Nordmannsfonna, high- to low-amplitude, gently east-dipping seismic reflections, which possibly represent sedimentary strata (light orange unit in Fig. 3e), are crosscut but not offset by moderately west-dipping, highamplitude planar reflections (blue lines in Fig. 3e). In NNE-SSW-trending cross sections, these high-amplitude, crosscutting seismic reflections appear sub-horizontal (blue lines in Fig. 3f). These crosscutting, west-dipping reflections are mildly folded in places and either terminate upwards within the suggested gently east-dipping sedimentary strata (light orange unit in Fig. 3e) or are truncated by the base-Pennsylvanian unconformity (white line in Fig. 3e). Downwards within the Kongsfjorden-Cowanodden fault zone (black lines in Fig. 3e), these inclined reflections can be vaguely traced as a series of discontinuous, subtle features (see blue lines in Fig. 3e). In the footwall of the Kongsfjorden-Cowanodden fault zone, the inclined reflections become more prominent again, still do not offset background reflections, and extend to depths of 3-3.5 s (TWT; blue lines in Fig. 3e). The high amplitude of these planar west-dipping reflections, the absence of offset across them, and their discontinuous geometries across the Agardhbukta Fault and the Kongsfjorden-Cowanodden fault zone suggest that they may represent dikes (see Phillips et al., 2018). Because they appear truncated by the base-Pennsylvanian unconformity, we suggest that such dikes were emplaced prior to development of this unconformity. The KongsfjordenCowanodden fault zone is folded into a broad, $15-20 \mathrm{~km}$ wide anticline and offset $>0.5 \mathrm{~s}$ (TWT) by the Agardhbukta Fault, whereas the west-dipping dikes (blue lines in Fig. 3e) and the gently east-dipping sedimentary strata they intrude (light orange unit in Fig. 3e) are only mildly folded and show no offset across the Agardhbukta Fault (Fig. 3e). These differences in deformation suggest that the latter were deformed during a mild episode of late contraction but not by the same early episode of intense contraction that resulted in macrofolding of the Kongsfjorden-Cowanodden fault zone.

Cretaceous dikes and sills. Near or at the surface, thin, kilometer-wide, lenticular packages of gently dipping, moderate-high-amplitude seismic reflections (black units in Fig. 3e and f) correlate with surface outcrops of Cretaceous sills of the Diabasodden Suite in eastern Spitsbergen (Senger et al., 2013; Dallmann, 2015). In places, these sills are associated with areas showing high-frequency disruptions of underlying sub-horizontal seismic reflections (dotted black lines in Fig. 3f) correlated with onshore occurrences of Pennsylvanian-Mesozoic sedimentary strata (Andresen et al., 1992; Haremo and Andresen, 1992; Dallmann, 2015). We interpret these areas of high-frequency disruption in otherwise relatively undisturbed and only mildly deformed Pennsylvanian-Mesozoic sedimentary strata as zones with occurrences of Cretaceous feeder dikes. Alternatively, disruption may be related to scattering and attenuation of seismic energy caused on the sills.

\subsubsection{Stappen High (northwestern Norwegian Barents Sea north of Bjørnøya)}

On the Stappen High between Bjørnøya and Spitsbergen (Fig. 1c), seismic reflections at a depth of 2-6s (TWT) are dominated by moderate- to high-amplitude reflections with limited $(<5 \mathrm{~km})$ lateral continuity showing asymmetric, dominantly SSW-leaning curving geometries with a width of a few hundred meters to a few kilometers (yellow lines within pink unit in Fig. 3c), i.e., analogous to those in folded Precambrian basement rocks farther north (Figs. 3a and 4a). These reflections are truncated by gently to moderately NNEdipping (and subsidiary SSW-dipping) disruption surfaces (black lines within pink and purple units in Fig. 3c), some of which connect upwards with shallow (0-2 s TWT), NNEdipping, high-angle listric disruptions near Bjørnøya in the south (red lines in Fig. 3c). Notably, major seismic reflections near the upwards termination of deep, moderatelygently NNE-dipping disruption surfaces display characteristic gently curving-upwards geometries (yellow lines within pink and purple units in Fig. 3c) and overlying seismic on- 

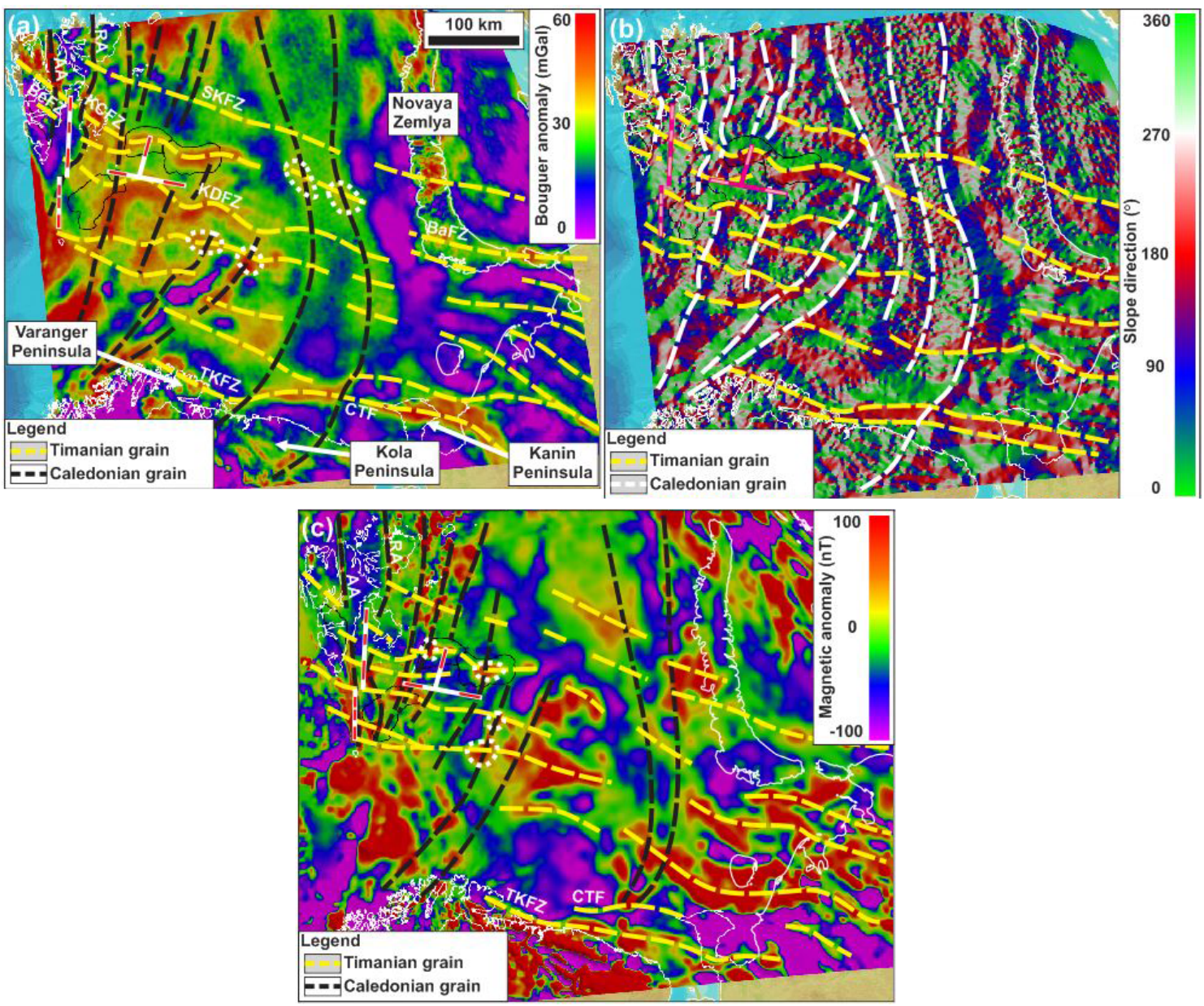

Figure 5. Gravimetric (a and b) and magnetic (c) anomaly maps over the Barents Sea and adjacent onshore areas in Russia (see location as a dashed white frame in Fig. 1b), Norway, and Svalbard showing E-W- to NW-SE-trending anomalies (dashed yellow lines) that correlate with the proposed NNE-dipping Timanian thrust systems in Svalbard and the northern Norwegian Barents Sea. Note the high obliquity of E-Wto NW-SE-trending Timanian grain with NE-SW- to N-S-trending Caledonian grain (dashed black and white lines). Note that dashed lines in (a) and (c) denote high gravimetric and magnetic anomalies. Also notice the oval-shaped high gravimetric and magnetic anomalies (dotted white lines) at the intersection of WNW-ESE- and N-S- to NNE-SSW-trending anomalies in (a) and (c) resulting from the interaction of the two (Timanian and Caledonian) thrust-and-fold trends. The locations of seismic profiles presented in Fig. 3a-d are shown as thick white lines in (a) and (c) and as fuchsia lines in (b). Within these thick white and fuchsia lines, the location and extent of thrust systems evidenced on seismic data (Fig. 3) are shown in white in (a) and (c) and in pink in (b). For the E-W-trending seismic profile shown in Fig. 3b, this implies that the red and pink lines represent N-S-trending synclines. Abbreviations are as follows. AA: Atomfjella Antiform; BaFZ: Baidaratsky fault zone; BeFZ: Bellsundbanken fault zone; CTF: Central Timan Fault; KCFZ: Kongsfjorden-Cowanodden fault zone; KDFZ: Kinnhøgda-Daudbjørnpynten fault zone; RA: Rijpdalen Anticline; SKFZ: Steiløya-Krylen fault zone; TKFZ: Trollfjorden-Komagelva Fault Zone.

laps (white half arrows in Fig. 3c) similar to those observed just south of major NNE-dipping thrust systems in Storfjorden and the northeastern Norwegian Barents Sea (Fig. 3a and Supplement S2).

We interpret deep (2-6 s TWT), curving, discontinuous seismic reflections (yellow lines within pink and purple units in Fig. 3c) as folded Precambrian-lower Paleozoic basement rocks and dominantly NNE-dipping disruption surfaces (black lines within pink and purple units in Fig. 3) as brittle-ductile thrust possibly partly mylonitic, though with less intense deformation than the major NNE-dipping thrust systems observed farther north in Storfjorden and the northeastern Norwegian Barents Sea, like the KongsfjordenCowanodden fault zone. These brittle-ductile thrusts can be traced eastwards on seismic data on the Stappen High and into the Sørkapp Basin (Fig. 1c).

Based on their geometries and on gentle folding of the seafloor reflection (yellow lines within green unit in Fig. 3c), shallow, NNE-dipping, high-angle listric disruptions are interpreted as mildly inverted normal faults overprinting 
deep NNE-dipping thrusts. Based on previous fieldwork on Bjørnøya (Worsley et al., 2001), seismic mapping in the area (Lasabuda et al., 2018), and well ties to Hopen and Edgeøya, relatively continuous $(>5 \mathrm{~km})$, shallow $(0-2 \mathrm{~s}$ TWT), gently curved-undulating seismic reflections overlying folded Precambrian-lower Paleozoic basement rocks are interpreted as mildly folded upper Paleozoic-Mesozoic (-Cenozoic?) sedimentary strata (orange and green units in Fig. 3c).

\subsection{Potential field data and regional gravimetric and magnetic anomalies}

\subsubsection{NNE-dipping thrusts}

In the northern Barents Sea, Storfjorden, and centraleastern Spitsbergen, the seismic occurrences of the Kongsfjorden-Cowanodden, Bellsundbanken, and Kinnhøgda-Daudbjørnpynten fault zones coincide with gradual, step-like, southwards increases in gravimetry and, in places, with high magnetic anomalies in cross section (Fig. 3a, b and d, f). Similar southwards gradual and step-like increases in the Bouguer and magnetic anomalies correlate with major thrusts north of Bjørnøya (Fig. 3c; see Fig. 1b for location of Bjørnøya). These patterns suggest that the footwall of the thrust systems consists of relatively denser rock units, possibly with higher metamorphic grade. Seismic interpretation showing thickening of metamorphosed and folded Precambrian basement rock units (pink unit in Fig. 3a and $c, d$ ) in the footwall of the thrusts further supports this claim.

In map-view gravimetric and magnetic data, the three thrust systems in Storfjorden (black lines in Fig. 3a) coincide with three high, WNW-ESE-trending, continuous, gently undulating (and, in place, merging and/or splaying) gravimetric and discontinuous magnetic anomalies (dashed yellow lines in Fig. 5a-c) that are separated from each other by areas showing relatively low gravimetric and magnetic anomalies (e.g., see green to blue areas in Fig. 5a). Some of these anomalies extend from central Spitsbergen to Storfjorden and the northern Barents Sea (below the Ora and Olga basins) as curving, E-W- and NW-SE-trending, $50-100 \mathrm{~km}$ wide anomalies (dashed yellow lines in Fig. 5a-c). Analogously, thrust systems north of Bjørnøya (Fig. 3c) and north of the Ora and Olga basins (Supplement S2b) correlate with comparable WNW-ESE-trending, curving magnetic and gravimetric anomalies (dashed yellow lines in Fig. 5a-c). The WNW-ESE-trending anomalies appear clearer by using a slope-direction shader for gravimetric data, which accentuates the contrast between each trend of anomalies (green and red areas in Fig. 5b).

Most of the recognized regional WNW-ESE-trending magnetic and gravimetric anomalies (dashed yellow lines in Fig. 5a-c) can be traced into the Russian Barents Sea where they are linear and crosscut by major N-S- to NNW-SSEtrending anomalies (dashed black and white lines in Fig. 5a- c). Subtle WNW-ESE-trending magnetic and gravimetric anomalies further extend onshore in northwestern Russia (e.g., Kanin Peninsula and southern Novaya Zemlya) where they correlate with major Timanian thrusts and folds, some of which are suspected to extend thousands of kilometers between northwestern Russia and the Varanger Peninsula in northern Norway (e.g., Trollfjorden-Komagelva Fault Zone and Central Timan Fault and associated Mikulkin Antiform; Siedlecka, 1975; Siedlecka and Roberts, 1995; Olovyanishnikov et al., 2000; Lorenz et al., 2004; Kostyuchenko et al., 2006). In addition, two of the southernmost WNWESE-trending gravimetric and magnetic anomalies coincide with the location of well-known, crustal-scale, SSW-verging Timanian thrust faults, the Trollfjorden-Komagelva Fault Zone, and the Central Timan Fault. Thus, based on their overall WNW-ESE trend, patterns of alternating highs and lows for both gravimetric and magnetic anomalies (see Fig. 5a), the location at the boundary of oppositely dipping slopes (see slope-direction shader map in Fig. 5b), and extensive field studies and seismic and well data in northwestern Russia (e.g., Kanin Peninsula and Timan Range; Siedlecka and Roberts, 1995; Olovyanishnikov et al., 2000; Lorenz et al., 2004; Kostyuchenko et al., 2006), northern Norway (e.g., Varanger Peninsula; Siedlecka, 1975), and the southeastern Norwegian Barents Sea (Hassaan et al., 2021), WNWESE-trending anomalies are interpreted as a combination of basement-seated Timanian macro-folds and top-SSW reverse faults (Fig. 5a-c).

\subsubsection{N-S-trending folds}

Large N-S-trending open folds (e.g., black and yellow lines in Fig. 3b) coincide with N-S- to NNE-SSW-trending, 20$100 \mathrm{~km}$ wide, arcuate gravimetric and magnetic anomalies (dashed white and black lines in Fig. 5a-c), which are highly oblique to WNW-ESE-trending gravimetric and magnetic anomalies and thrust systems (dashed yellow lines in Fig. 5ac). Notably, major N-S- to NNE-SSW-trending synclines in Fig. 3b (marked as red lines over a white line in Fig. 5a and c and as pink lines over a red line in Fig. 5b) coincide with similarly trending gravimetric and magnetic anomalies (dashed black lines in Fig. 5a and c and dashed white lines in Fig. 5b). On the slope-direction shader map of gravimetric data, these $\mathrm{N}-\mathrm{S}$ - to NNE-SSW-trending anomalies are localized along the boundary between areas with eastwards- (ca. 90-100'; blue areas in Fig. 5b) and westwards-facing slopes (ca. 270$280^{\circ}$; white areas in Fig. 5b).

Notably, where the main thrusts are preserved, major $\mathrm{N}-\mathrm{S}$-trending synforms (see 50-60 km wide U-shaped depression formed by the Kinnhøgda-Daudbjørnpynten fault zone, i.e., black lines, in Fig. 3b) coincide with gravimetric and magnetic highs (white and black dashed lines in Fig. 5a-c), whereas major antiforms where major NNEdipping thrusts are partly eroded (e.g., ca. $100 \mathrm{~km}$ wide areas where the Kinnhøgda-Daudbjørnpynten fault zone is absent 
in Fig. 3b) coincide with gravimetric and magnetic lows (the lows are parallel to white and black dashed lines symbolizing magnetic and gravimetric highs in Fig. 5a-c). The correlation of the interpreted NNE-dipping thrust systems with gravimetric highs suggests that the thrusts consist of relatively denser rocks. This supports the inferred mylonitic (i.e., higher metamorphic grade) component of the thrusts because mylonites are relatively denser due to the formation of highdensity minerals with increasing deformation (e.g., Arbaret and Burg, 2003; Colombu et al., 2015).

In the northwestern part of the Barents Sea (i.e., area covered by seismic data presented in Fig. 3), N-S- to NNESSW-trending gravimetric and magnetic anomalies (white and black dashed lines in Fig. 5a-c) are typically $20-50 \mathrm{~km}$ wide and correlate with similarly trending Caledonian folds and thrusts in onshore Nordaustlandet (e.g., Rijpdalen Anticline; Johansson et al., 2004, 2005; Dumais and Brönner, 2020) and northeastern Spitsbergen (e.g., Atomfjella Antiform; Gee et al., 1994; Witt-Nilsson et al., 1998), whose width is comparable to that of the anomalies. In the south, N$\mathrm{S}$ - to NNE-SSW-trending gravimetric and magnetic anomalies merge together and swing into a NE-SW trend in the onshore-nearshore area of the Kola Peninsula and northern Norway. These anomalies mimic the attitude of Caledonian thrusts and folds in the southern Norwegian Barents Sea (Gernigon and Brönner, 2012; Gernigon et al., 2014) and onshore northern Norway (Sturt et al., 1978; Townsend, 1987; Roberts and Williams, 2013). In the east, N-S- to NNESSW-trending anomalies broaden to up to $150 \mathrm{~km}$ in the Russian Barents Sea (Fig. 5a-c).

In places, the intersections of high, WNW-ESE- and N-Sto NNE-SSW-trending gravimetric and magnetic anomalies generate relatively higher, oval-shaped anomalies (e.g., dotted white lines in Fig. 5a and c). Notable examples are found in the Ora and Olga basins as well as east and south of these basins (see dotted white lines in Fig. 5a and c).

\section{Discussion}

In the discussion, we consider the lateral extent of the interpreted NNE-dipping thrust systems, their possible timing of formation, and potential episodes of reactivation and overprinting. Then we briefly discuss the implications of these thrust systems for plate tectonics reconstructions in the Arctic.

\subsection{Extent of NNE-dipping thrust systems}

Four major NNE-dipping systems of mylonitic thrusts and shear zones (Steiløya-Krylen, Kongsfjorden-Cowanodden, Bellsundbanken, Kinnhøgda-Daudbjørnpynten fault zones) were identified at depths $>1-2 \mathrm{~s}$ (TWT) in central-eastern Spitsbergen, Storfjorden, and the northeastern Barents Sea, as well as several systems with less developed ductile fab- rics between Spitsbergen and Bjørnøya on the Stappen High (Fig. 3a-f).

The Kongsfjorden-Cowanodden fault zone is relatively easy to trace and correlate in Sassenfjorden, Sassendalen, Nordmannsfonna, Storfjorden, and the northeastern Barents Sea (east of Edgeøya) because (i) the seismic data in the these areas have a high resolution and good coverage, (ii) internal seismic reflections are characterized by high amplitudes (e.g., brittle-ductile thrusts and mylonitic shear zones), (iii) kinematic indicators within the thrust system consistently show a dominantly top-SSW sense of shear with SSWverging fold structures (Fig. 3a and d-f, and Supplement S2), (iv) the geometry and kinematics indicators along shallow brittle overprints are regionally consistent (listric, downNNE, brittle normal faults; Fig. 3a and d-f), and (v) this thrust consistently coincides with an increase in gravimetric and magnetic anomalies in cross section (Fig. 3a and d) and with analogously trending gravimetric and magnetic anomalies in central-eastern Spitsbergen and the northern Barents Sea (Fig. 5a and b). This thrust system was previously identified below the Ora Basin by Klitzke et al. (2019), though it was interpreted as potential Timanian grain instead of a discrete structure. The proposed correlation based on seismic, cross-sectional, and map-view gravimetric and magnetic data suggests a lateral extent of ca. 550-600 km alongstrike for the Kongsfjorden-Cowanodden fault zone. However, the regional magnetic and gravimetric anomalies associated with this thrust in the Norwegian Barents Sea and Svalbard potentially extend farther east as a series of WNWESE-trending anomalies to the mainland of Russia (Fig. 5ac). Notably, these anomalies correlate with the southern edge of Novaya Zemlya (Fig. 5a-c) and, more specifically, with WNW-ESE-striking fault segments of the Baidaratsky fault zone (Fig. 1a; Lopatin et al., 2001; Korago et al., 2004), a major thrust fault that bounds a major basement high in the central Russian Barents Sea, the Ludlov Saddle (Johansen et al., 1992; Drachev et al., 2010). Thus, it is possible that the Kongsfjorden-Cowanodden fault zone also extends farther east, possibly merging with the Baidaratsky fault zone, i.e., with a minimum extent of $1700-1800 \mathrm{~km}$ (Fig. 5a-c). This is supported by a similar configuration of the Baidaratsky fault zone and the Kongsfjorden-Cowanodden fault zone, including a basement-seated, low-angle thrust geometry of both faults and inversion as a normal fault and deposition of sedimentary strata several seconds (TWT) thick in the hanging wall of the faults in the late Paleozoic (Fig. 3d and Smelror et al., 2009, their profile C-D pp. 53).

The overall NNE-dipping and folded (into NNE-plunging folds) geometry of the Kongsfjorden-Cowanodden fault zone (Fig. 3e and $\mathrm{f}$ and Klitzke et al., 2019, their Figs. 35) may explain the alternating NW-SE- and E-W-trending geometry of the gravimetric and magnetic anomalies correlating with this thrust system (Fig. 5a and b). E-W- and NW-SE-trending segments of these anomalies may respectively represent the western and eastern limbs of open, gently 
NNE-plunging macro-anticlines in the northern Norwegian Barents Sea. The relatively higher, oval-shaped gravimetric and magnetic anomalies at the intersection of WNW-ESEand N-S- to NNE-SSW-trending magnetic and gravimetric highs, which are interpreted as the interaction of two suborthogonal fold trends, further support this claim (Fig. 5a and c).

Interpretation of seismic sections (Fig. $3 \mathrm{e}$ and $\mathrm{f}$ and Supplement S2) and regional magnetic and gravimetric data (Fig. 5a-c) in central-eastern Spitsbergen shows that the NNE-dipping, top-SSW Kongsfjorden-Cowanodden and Bellsundbanken fault zones likely extend westwards into central (and possibly northwestern) Spitsbergen (e.g., Sassendalen, Sassenfjorden, Tempelfjorden, and Billefjorden; see Fig. 1c for locations). This is further supported by recent field, bathymetric, and seismic mapping in central Spitsbergen showing that (inverted) Devonian-Carboniferous NNE-dipping brittle normal faults in Billefjorden and Sassenfjorden-Tempelfjorden merge with kilometer-scale, NNE-dipping, Precambrian basement fabrics and shear zones at depth (Koehl, 2020, 2021; Koehl et al., 2021). Other examples of WNW-ESE-trending fabrics include faults within Precambrian basement and Carboniferous sedimentary rocks in northeastern Spitsbergen (WittNilsson et al., 1998; Koehl and Muñoz-Barrera, 2018) and within Devonian sedimentary rocks in northern and northwestern Spitsbergen (Friend et al., 1997; McCann, 2000; Dallmann and Piepjohn, 2020). These suggest a repeated and regional influence of WNW-ESE-trending thrust systems and associated basement fabrics in Spitsbergen.

Analogously to the Kongsfjorden-Cowanodden fault zone, the Bellsundbanken and Kinnhøgda-Daudbjørnpynten fault zone (Fig. 3a) geometries and kinematics on seismic data, and their coinciding with parallel gravimetric and magnetic anomalies in map view and with magnetic and gravimetric highs in cross section suggest that they extend from Storfjorden to the island of Hopen (Figs. 1c, 3a, 5a-c, and Supplement S2). Notably, a 50-100 km wide, NNE-SSWtrending gravimetric and associated magnetic anomaly interpreted as Caledonian grain in Nordaustlandet (Rijpdalen Anticline; Dumais and Brönner, 2020) bends across the trace of these two thrust systems (Fig. 5a-c). Farther east, the Bellsundbanken and Kinnhøgda-Daudbjørnpynten fault zones are parallel to gravimetric and magnetic, alternating E-Wand NW-SE-trending anomalies that follow the trends and map-view shapes of the Ora and Olga basins in the northeastern Norwegian Barents Sea (Anell et al., 2016; see Fig. 1b and $\mathrm{c}$ for location). This suggests that these two thrust systems extend into the northeastern Norwegian Barents Sea and potentially into the Russian Barents Sea and that they affected the development of Paleozoic sedimentary basins. This is also the case of the Steiløya-Krylen fault zone (Supplement S2b), which coincides with mild, discontinuous, WNW-ESE-trending gravimetric and magnetic anomalies that extend well into the Russian Barents Sea and possibly across Novaya Zemlya (Fig. 5a-c).

In southwestern Spitsbergen, field mapping revealed the presence of a major, sub-vertical, kilometer-thick, WNWESE-striking mylonitic shear zone metamorphosed under amphibolite facies conditions: the Vimsodden-Kosibapasset Shear Zone (Majka et al., 2008, 2012; Mazur et al., 2009; see Fig. 1c for location). This major sinistral shear zone aligns along a WNW-ESE-trending axis with the KinnhøgdaDaudbjørnpynten fault zone in the northwestern Norwegian Barents Sea (Fig. 3a) and shows a folded geometry in map view that is comparable to that of major NNE-dipping thrust systems in the northern Norwegian Barents Sea (Figs. 3a and e, f, 5a-c, and Supplement S2; Klitzke et al., 2019). In addition, the Vimsodden-Kosibapasset Shear Zone juxtaposes relatively old Proterozoic basement rocks in the north against relatively young rocks in the south, thus suggesting a similar configuration and kinematics as along the KinnhøgdaDaudbjørnpynten fault zone in Storfjorden and the northeastern Norwegian Barents Sea. Moreover, von Gosen and Piepjohn (2001) and Bergh and Grogan (2003) reported that Devonian-Mississippian sedimentary successions and Cenozoic fold structures (e.g., Hyrnefjellet Anticline) are offset sinistrally by a few kilometers in Hornsund. Thus, we propose that the Vimsodden-Kosibapasset Shear Zone extends into Hornsund and represents the westwards continuation of the Kinnhøgda-Daudbjørnpynten fault zone. This suggests a minimum extent of $400-450 \mathrm{~km}$ for this thrust system (Figs. 1b, c and 5a-c).

\subsection{Timing of formation of major NNE-dipping thrust systems and N-S-trending folds}

\subsubsection{NNE-dipping thrust systems}

The thickness of several kilometers and along-strike extent of hundreds to thousands of kilometers of NNE-dipping thrust systems in central-eastern Spitsbergen, Storfjorden, and the northwestern and northeastern Norwegian Barents Sea suggest that they formed during a major contractional tectonic event. The overall WNW-ESE trend and the consistent north-northeastwards dip and top-SSW sense of shear along the newly evidenced deep thrust systems preclude formation during the Grenvillian, Caledonian, and Ellesmerian orogenies, as well as the Eurekan tectonic event. These tectonic events all involved dominantly E-W-oriented contraction and resulted in the formation of overall N-S- to NNESSW-trending fabrics, structures, and deformation belts in Svalbard (i.e., sub-orthogonal to the newly identified thrust systems) such as the Atomfjella Antiform (Gee et al., 1994; Witt-Nilsson et al., 1998), the Vestfonna and Rijpdalen anticlines (Johansson et al., 2004, 2005; Dumais and Brönner, 2020), the Dickson Land and Germaniahalvøya foldthrust zones (McCann, 2000; Piepjohn, 2000; Dallmann and Piepjohn, 2020), and the West Spitsbergen Fold-and-Thrust 
Belt and related early Cenozoic structures in eastern Spitsbergen (Andresen et al., 1992; Haremo and Andresen, 1992; Dallmann et al., 1993), as well as NE-SW- to NNE-SSWstriking thrusts and folds in northern Norway (Sturt et al., 1978; Townsend, 1987; Roberts and Williams, 2013) and the southwestern Barents Sea (Gernigon et al., 2014).

A possible cause for the formation of the observed NNEdipping thrust systems is the late Neoproterozoic Timanian Orogeny, which is well known in onshore northwestern Russia (e.g., Kanin Peninsula, Timan Range, and central Timan; Siedlecka and Roberts, 1995; Olovyanishnikov et al., 2000; Lorenz et al., 2004; Kostyuchenko et al., 2006) and northeastern Norway (Varanger Peninsula; Siedlecka and Siedlecki, 1967; Siedlecka, 1975; Roberts and Olovyanishnikov, 2004), traces of which were recently found in the southeastern Norwegian Barents Sea (Hassaan et al., 2020a, b, 2021; Hassaan, 2021), southwestern Spitsbergen (Majka et al., 2008, 2012, 2014), and northern Greenland (Rosa et al., 2016; Estrada et al., 2018). The overall transport direction during this orogeny was directed towards the south-southwest, and most thrust systems show NNEdipping geometries (Olovyanishnikov et al., 2000; Lorenz et al., 2004; Kostyuchenko et al., 2006), e.g., the Timanian thrust front on the Varanger Peninsula in northeastern Norway (Trollfjorden-Komagelva Fault Zone; Siedlecka and Siedlecki, 1967; Siedlecka, 1975) and its eastwards continuation, the Central Timan Fault (Lorenz et al., 2004; Kostyuchenko et al., 2006). In addition, the sizes of Timanian thrust systems and related thrust anticlines in the Timan Range and Kanin Peninsula (e.g., Central Timan Fault and Mikulkin Antiform) are comparable ( $\geq 3-4$ s TWT thick thrusts and $5-15 \mathrm{~km}$ wide thrust-related major anticlines; Lorenz et al., 2004 their Figs. 3 and 5; Kostyuchenko et al., 2006 their Fig. 17) to that of thrust-and-fold systems in the northern Norwegian Barents Sea and Svalbard (Fig. 3a and c, d).

Thus, based on their overall WNW-ESE strike (Fig. 1b and c), their vergence to the south-southwest (Fig. 3a, c, d and $\mathrm{f}$ ), their coincidence with gravimetric and magnetic highs (Fig. 5a-c), their upward truncation by a major unconformity consistently throughout the study area (see top-Precambrian unconformity in Fig. 3a-d), and the correlation of these NNE-dipping thrusts and associated major anticlines (via gravimetric and magnetic anomalies) with similarly striking and verging structures of comparable size (i.e., several seconds TWT thick, 5-15 km wide anticlines) in the onshorenearshore area of northwestern Russia and northern Norway (Siedlecka, 1975; Siedlecka and Roberts, 1995; Olovyanishnikov et al., 2000; Roberts and Siedlecka, 2002; Lorenz et al., 2004; Gee and Pease, 2004; Kostyuchenko et al., 2006), NNE-dipping thrusts in the northern Norwegian Barents Sea, Storfjorden, and central-eastern Spitsbergen are interpreted as the western continuation of Timanian thrust and fold systems.
Timanian grain was recently identified in the northeastern Norwegian Barents Sea through interpretation of new seismic, magnetic, and gravimetric datasets shown in Fig. 5ac (Klitzke et al., 2019). The alignment, coincident location, and matching geometries (e.g., curving E-W to NW-SE strike or trend and kilometer-wide NNE-SSW-trending anticline) between Timanian grain and structures mapped by Klitzke et al. (2019) and the major, NNE-dipping, top-SSW thrust systems described in central-eastern Spitsbergen, Storfjorden, and the Norwegian Barents Sea (Fig. 3a-f and Supplement S2) further support a Timanian origin for the latter. Further evidence of relic Timanian structural grain as far as the Loppa High and Bjørnøya Basin are documented by previous magnetic studies and modeling (Marello et al., 2010). Moreover, seismic mapping suggests that Timanian thrust systems extend well into central Spitsbergen (Fig. 3e and $f$ and Supplement S2c and d; Koehl, 2020, 2021; Koehl et al., 2021), and regional gravimetric and magnetic anomaly maps suggest that Timanian thrust systems might extend farther west to (north)western Spitsbergen (Fig. 5a-c).

Probable reasons as to why these major (hundreds to thousands of kilometers long) thrust systems were not identified before during fieldwork in Svalbard are their burial to high depth ( $>1-2 \mathrm{~s}$ TWT in the study area, i.e., several kilometers below the surface; Fig. 3a-f) and their strong overprinting by younger tectonic events like the Caledonian Orogeny in areas where they are exposed (e.g., Vimsodden-Kosibapasset Shear Zone in southwestern Spitsbergen; Faehnrich et al., 2020). Possible areas of interest for future studies include the western and northwestern parts of Spitsbergen where Caledonian and Eurekan E-W contraction contributed to uplift and exhumation of deep basement rocks and where Timanian rocks potentially crop out (e.g., Peucat et al., 1989).

\subsubsection{N-S-trending folds}

$\mathrm{N}-\mathrm{S}$-trending upright folds involve the NNE-dipping thrust systems (Fig. 3b and e) and correlate (via gravimetric and magnetic anomalies) with major Caledonian folds in northeastern Spitsbergen and Nordaustlandet, like the Atomfjella Antiform (Gee et al., 1994; Witt-Nilsson et al., 1998) and Rijpdalen Anticline (Johansson et al., 2004, 2005; Dumais and Brönner, 2020), with Caledonian grain in the southern Norwegian Barents Sea (Gernigon and Brönner, 2012; Gernigon et al., 2014), and with major NE-SW-trending Caledonian folds in onshore northern Norway (Sturt et al., 1978; Townsend, 1987; Roberts and Williams, 2013). In addition, the width of the NE-SW- to N-S-trending gravimetric and magnetic anomalies associated with these folds increases up to $150 \mathrm{~km}$ eastwards, i.e., away from the Caledonian collision zone (Fig. 5a-c; Corfu et al., 2014; Gasser, 2014). Thus, $\mathrm{N}-\mathrm{S}$-trending folds in the northern Norwegian Barents Sea are interpreted as Caledonian regional folds in Precambrianlower Paleozoic rocks. The relatively broader geometry of Caledonian folds away from the Caledonian collision zone 


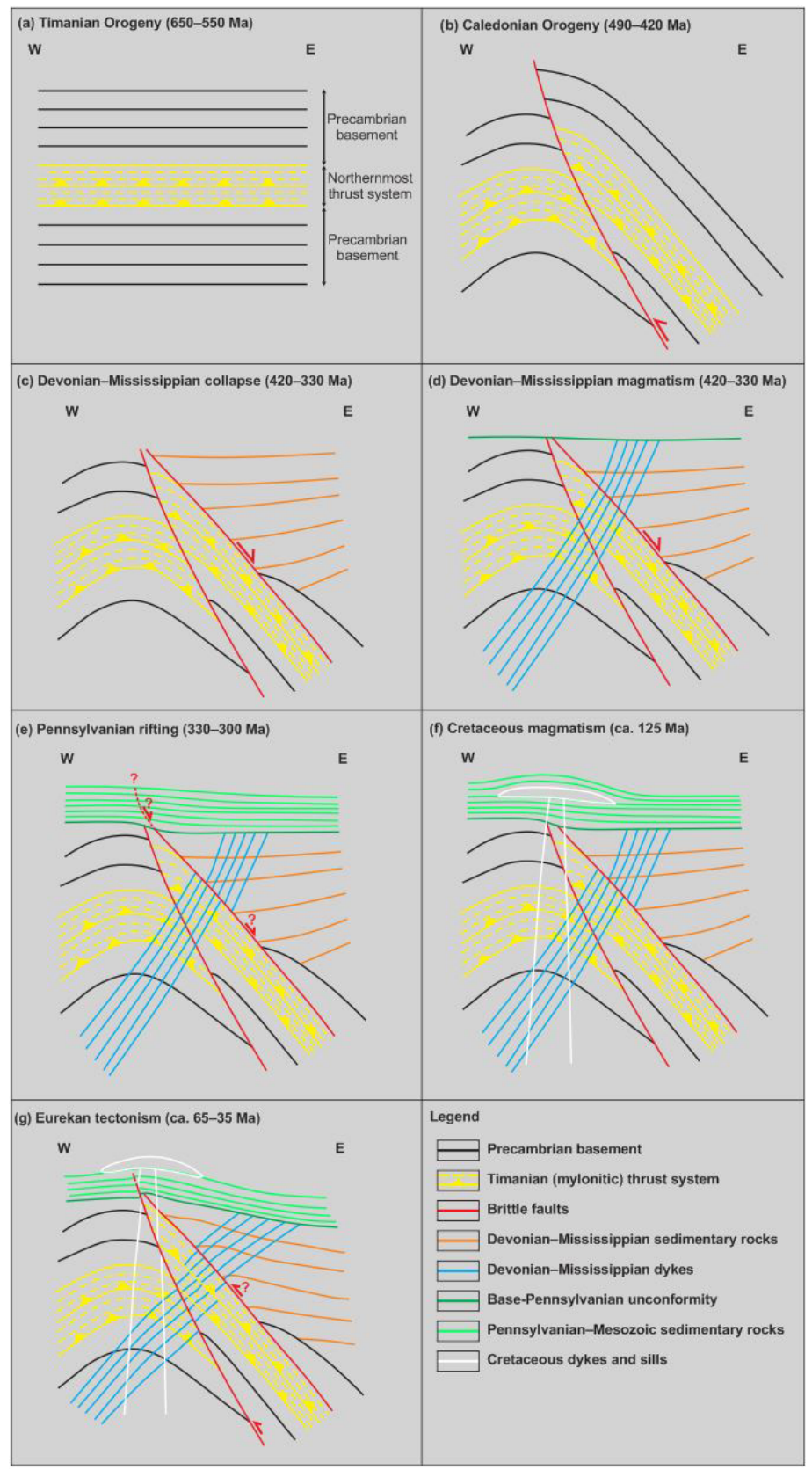

Figure 6. Sketches showing a possible reconstruction of the tectonic history of the E-W seismic profile in Nordmannsfonna shown in Fig. 3e. (a) Formation of a NNE-dipping, mylonitic thrust system (Kongsfjorden-Cowanodden fault zone) within Precambrian basement rocks during the Timanian Orogeny in the latest Neoproterozoic. The NNE-dipping Kongsfjorden-Cowanodden fault zone appears nearly horizontal on the E-W transect. (b) Top-west thrusting along the east-dipping Agardhbukta Fault and folding of the Kongsfjorden-Cowanodden fault zone into a broad, moderately NNE-plunging anticline during the Caledonian Orogeny. (c) Inversion of the Kongsfjorden-Cowanodden fault zone along the eastern flank of the Caledonian anticline and deposition of thickened, gently west-dipping, syn-tectonic, Devonian (-Mississippian?) sedimentary strata during post-Caledonian collapse-related extension. (d) Intrusion of Precambrian basement and Devonian (-Mississippian?) sedimentary rocks by steeply west-dipping dikes in the Devonian-Mississippian. (e) Regional erosion in the midCarboniferous (latest Mississippian) and deposition of Pennsylvanian sedimentary strata, possibly along a high-angle brittle splay of the inverted portion of the Kongsfjorden-Cowanodden fault zone during rift-related extension. (f) Deposition of Mesozoic sedimentary strata and intrusion of Cretaceous dolerite dikes and sills. (g) Erosion of Pennsylvanian-Mesozoic strata and reactivation of the KongsfjordenCowanodden fault zone and Agardhbukta Fault with minor reverse movements in the early Cenozoic during the Eurekan tectonic event as shown by mild folding and offset of overlying post-Caledonian sedimentary strata, dikes, and base-Pennsylvanian unconformity. Also note the back-tilting (i.e., clockwise rotation) of Devonian-Mississippian dikes in the hanging wall of the Agardhbukta Fault and of the Kongsfjorden-Cowanodden fault zone. 
(e.g., in the Russian Barents Sea) is inferred to be related to gentler fold geometries due to decreasing deformation intensity in this direction. This is further supported by relatively low-grade Caledonian metamorphism in Franz Josef Land (Knudsen et al., 2019; see Fig. 1a and b for location). By contrast, the presence of tighter Caledonian folds near the collision zone in the northern Norwegian Barents Sea (e.g., Fig. $3 \mathrm{~b}$ and e, and Atomfjella Antiform and Rijpdalen Anticline onshore; Gee et al., 1994; Witt-Nilsson et al., 1998; Johansson et al., 2004, 2005; Dumais and Brönner, 2020) is associated with much narrower (20-50 km wide) gravimetric and magnetic anomalies (Fig. 5a-c). Note that the Atomfjella Antiform and Rijpdalen Anticline can be directly correlated with $20-50 \mathrm{~km}$ wide, $\mathrm{N}-\mathrm{S}$-trending high gravimetric and magnetic anomalies (Fig. 5a-c). It is noteworthy that some of the NNE-SSW-trending folds and anomalies in the northernmost Norwegian Barents Sea may reflect a combination of Caledonian and superimposed early Cenozoic Eurekan folding (e.g., Kairanov et al., 2018).

The interference of WNW-ESE- and N-S- to NNE-SSWtrending gravimetric highs, which are correlated with Timanian and Caledonian folds, respectively, produces ovalshaped gravimetric and magnetic highs (Fig. 5a). These relatively higher, oval-shaped gravimetric anomalies are interpreted to correspond to dome-shaped folds resulting from the interaction of Timanian and Caledonian folds involving refolding of WNW-ESE-trending Timanian folds during E-W Caledonian contraction. Field studies on the Varanger Peninsula in northern Norway and seismic studies of Timanian thrusts off northern Norway where the interaction of Timanian and Caledonian folds produced dome-shaped fold structures (Ramsay, 1962), e.g., the Ragnarokk Anticline (Siedlecka and Siedlecki, 1971; Koehl, 2021) also support this interpretation. Furthermore, Barrère et al. (2011) suggested that basins and faults in the southern Norwegian Barents Sea are controlled by the interaction of Caledonian and Timanian structural grain, and Marello et al. (2010) argued that elbow-shaped magnetic anomalies reflect the interaction of Caledonian and Timanian structural grains in the Barents Sea, potentially as far west as the Loppa High and the Bjørnøya Basin.

\subsection{Phanerozoic reactivation and overprinting of Timanian thrust systems}

\subsubsection{Caledonian reactivation and overprint}

The geometry of the Kongsfjorden-Cowanodden and Kinnhøgda-Daudbjørnpynten fault zones in Nordmannsfonna (Fig. 3e) and in the northeastern Norwegian Barents Sea (Fig. 3b; Klitzke et a., 2019), where they are folded into broad NNE-plunging upright anticlines and synclines, suggests that these thrust systems were deformed after they accommodated top-SSW Timanian thrusting (Figs. 6a and $7 \mathrm{a}$ ). In addition, subsidiary top-west kinematics (west- verging folds and top-west minor thrusts) suggest that Timanian thrust systems were partly reactivated-overprinted during an episode of intense E-W contraction (Figs. 6b and 7b). However, west-dipping dikes crosscutting and gently east-dipping sedimentary strata overlying the eastern part of the folded Kongsfjorden-Cowanodden fault zone are only mildly folded, and upper Paleozoic sedimentary strata lie flat over folded and partly eroded Precambrian-lower Paleozoic rocks and the Kinnhøgda-Daudbjørnpynten fault zone, thus suggesting that these sedimentary strata and dikes were not involved in this episode of E-W contraction (Fig. 3e).

A notable episode of $\mathrm{E}-\mathrm{W}$ contraction in Svalbard is the Caledonian Orogeny in the early to mid-Paleozoic, which resulted in the formation of west-verging thrusts and $\mathrm{N}-\mathrm{S}$-trending folds of a size comparable (ca. 15-25 km wide) to those affecting the Kongsfjorden-Cowanodden and Kinnhøgda-Daudbjørnpynten fault zones in Nordmannsfonna and the northern Norwegian Barents Sea (Fig. 3b and e; Klitzke et al., 2019, their Figs. 3-5), such as the Atomfjella Antiform in northeastern Spitsbergen (Gee et al., 1994; Witt-Nilsson et al., 1998; Lyberis and Manby, 1999) and the Rijpdalen Anticline in Nordaustlandet (Fig. 1b). Since the NNE-plunging anticline in Nordmannsfonna does not affect overlying Pennsylvanian-Mesozoic sedimentary strata (Fig. 3e), we propose that they formed during Caledonian contraction (Fig. 7b). This is supported by the involvement of the top-Precambrian unconformity and underlying NNEdipping thrusts in N-S- to NNE-SSW-trending folds and by the truncation of these folds by the top-Silurian unconformity, which is onlapped by mildly deformed to flat-lying upper Paleozoic strata (Figs. 3b and 4f). Furthermore, structures with geometries comparable to NNE-plunging folds in the northern Barents Sea and Svalbard were observed in northern Norway. An example is the Ragnarokk Anticline, a domeshaped fold structure along the Timanian front thrust on the Varanger Peninsula, which results from the refolding of Timanian thrusts and folds into a NE-SW-trending Caledonian trend (Siedlecka and Siedlecki, 1971).

Further support of a Caledonian origin for upright NNEplunging folds in eastern Spitsbergen, Storfjorden, and the northern Norwegian Barents Sea is that these folds are relatively tight in the west, in Nordmannsfonna, and the northwestern Barents Sea (Fig. 3b and e), whereas they show gradually gentler and more open geometries in the east, i.e., away from the Caledonian collision zone (Fig. 3b). This is also shown by the gradual eastwards broadening of regional gravimetric and magnetic anomalies correlated with Caledonian folds, suggesting gentler fold geometries related to decreasing (Caledonian) deformation intensity in this direction (Figs. 5a-c and 7b). This contrasts with the homogeneous intensity of deformation along NNE-dipping thrusts on NNESSW-trending seismic profiles and with the homogeneous width of related gravimetric-magnetic anomalies from west to east in Svalbard and the Barents Sea (Figs. 3a-f and 5a-c and Supplement S2). Caledonian folding of Timanian thrusts 


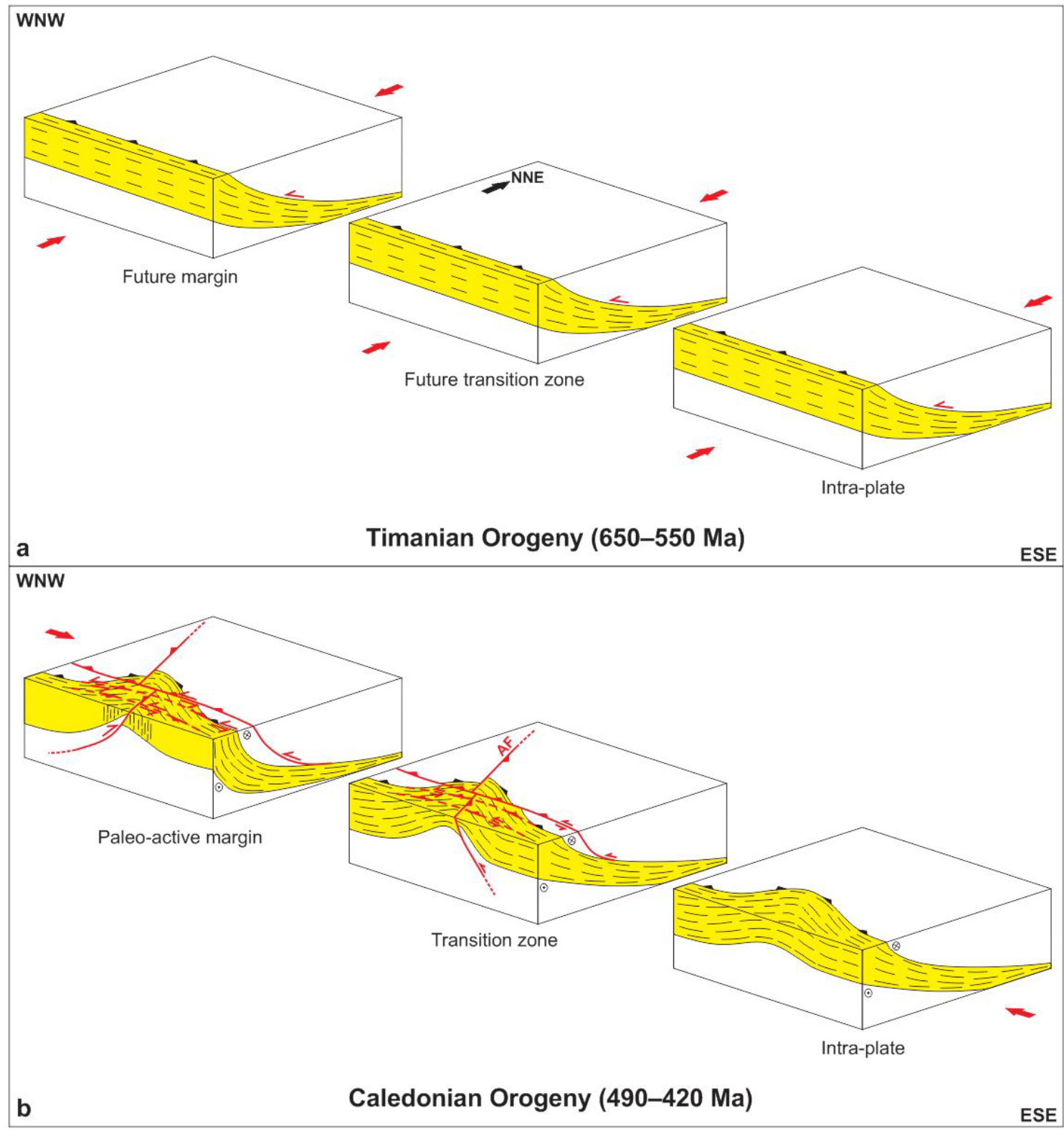

Figure 7.

also explains the weaker magnetic and gravimetric signal of Timanian faults at the location of major Caledonian synclines where Timanian faults were transported downwards and therefore may not show well on potential field data (e.g., two major NE-SW- to $\mathrm{N}-\mathrm{S}$-trending, negative gravimetric anomalies in the Russian Barents Sea just west of Novaya Zemlya; Fig. 5a).

In Nordmannsfonna, the Caledonian origin of the major $15-20 \mathrm{~km}$ wide anticline and the truncation of overlying, gently east-dipping, mildly folded sedimentary strata and crosscutting west-dipping dikes by the base-Pennsylvanian unconformity suggest that these sedimentary strata and dikes are Devonian (-Mississippian?) in age (Fig. 6c and d). This is supported by the presence of thick Devonian-Mississippian collapse deposits in adjacent areas of central-northern Spitsbergen (Cutbill et al., 1976; Murascov and Mokin, 1979; Aakvik, 1981; Gjelberg, 1983; Manby and Lyberis, 1992; Friend et al., 1997) and by Middle Devonian to Mississippian ages (395-327 Ma) for dikes in central-northern Spitsbergen (Evdokimov et al., 2006), northern Norway (Lippard and Prestvik, 1997; Guise and Roberts, 2002), and northwestern Russia (Roberts and Onstott, 1995).

The occurrence of a $>0.5 \mathrm{~s}$ (TWT) reverse offset of the folded Kongsfjorden-Cowanodden fault zone and the lack of offset of the Devonian (-Mississippian?) dikes across the Agardhbukta Fault indicate that the latter fault formed as a 


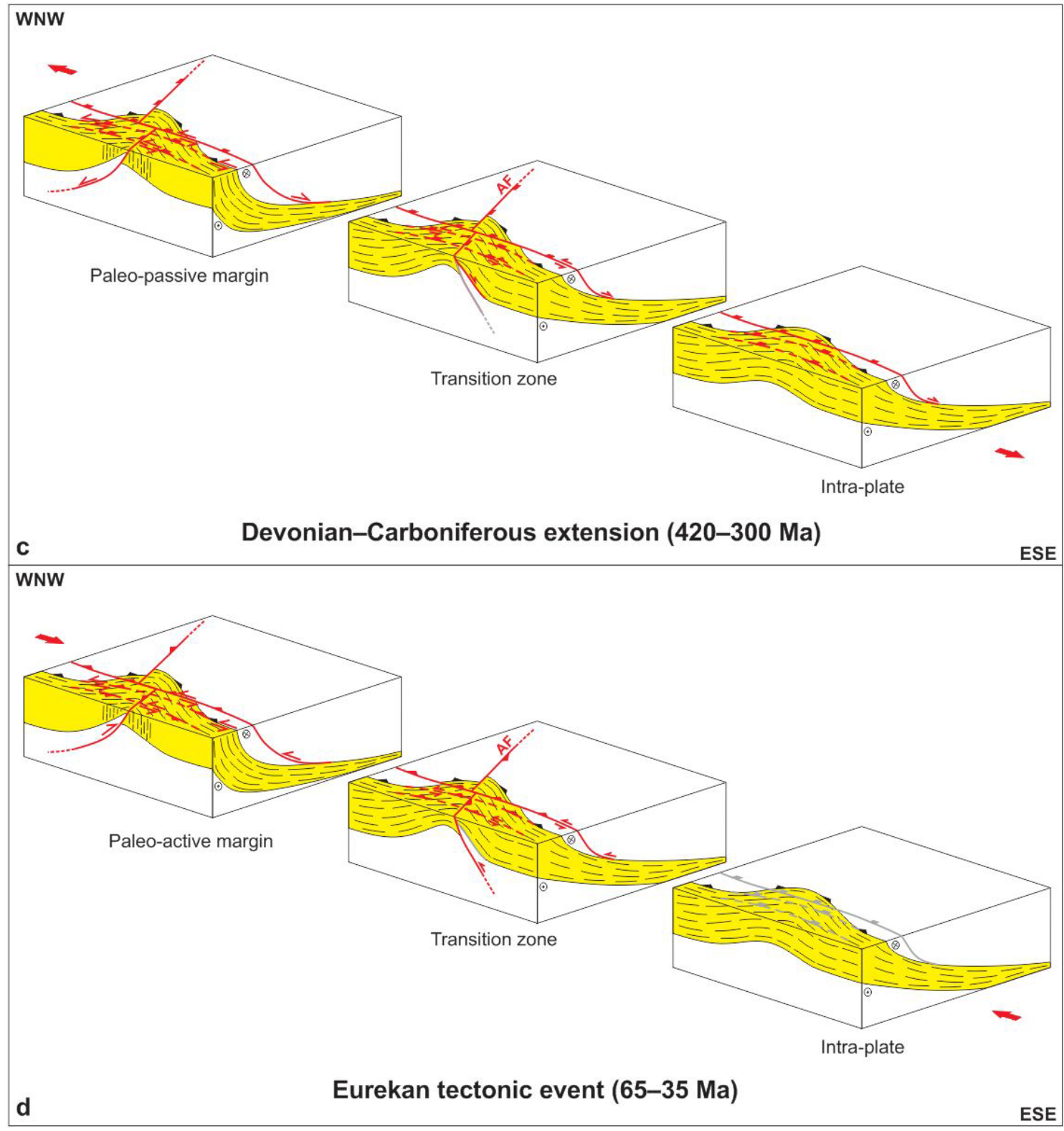

Figure 7.

top-west thrust during the Caledonian Orogeny. At depth, the Agardhbukta Fault merges with the eastern flank of the folded Kongsfjorden-Cowanodden fault zone. This, together with the presence of minor, high-angle, top-west brittle thrusts within the Kongsfjorden-Cowanodden fault zone (Fig. 3e), indicates that the Agardhbukta Fault reactivated and/or overprinted the eastern portion of the KongsfjordenCowanodden fault zone in Nordmannsfonna during Caledonian contraction (Figs. 6b and 7b). Depth conversion using seismic velocities from Gernigon et al. (2018) suggest that the Agardhbukta Fault offset the Kongsfjorden-Cowanodden fault zone by ca. $2.4-2.5 \mathrm{~km}$ top-west during Caledonian contraction (Fig. 3e and Supplement S3g). These kinemat- ics are consistent with field observations in eastern Spitsbergen by Piepjohn et al. (2019, their Fig. 17b). However, Piepjohn et al. (2019) also suggested a significant component of Mesozoic-Cenozoic, down-east normal movement, which was not identified on seismic data in Nordmannsfonna. This suggests either along-strike variation in the movement history of the Agardhbukta Fault or that the fault mapped on seismic data in Nordmannsfonna does not correspond to the Agardhbukta Fault of Piepjohn et al. (2019).

Considering the presence of crustal-scale, NNE-dipping thrust systems that are hundreds (to thousands?) of kilometers long (Timanian) extending from the Barents Sea (and possibly from onshore Russia) to central-eastern and south- 


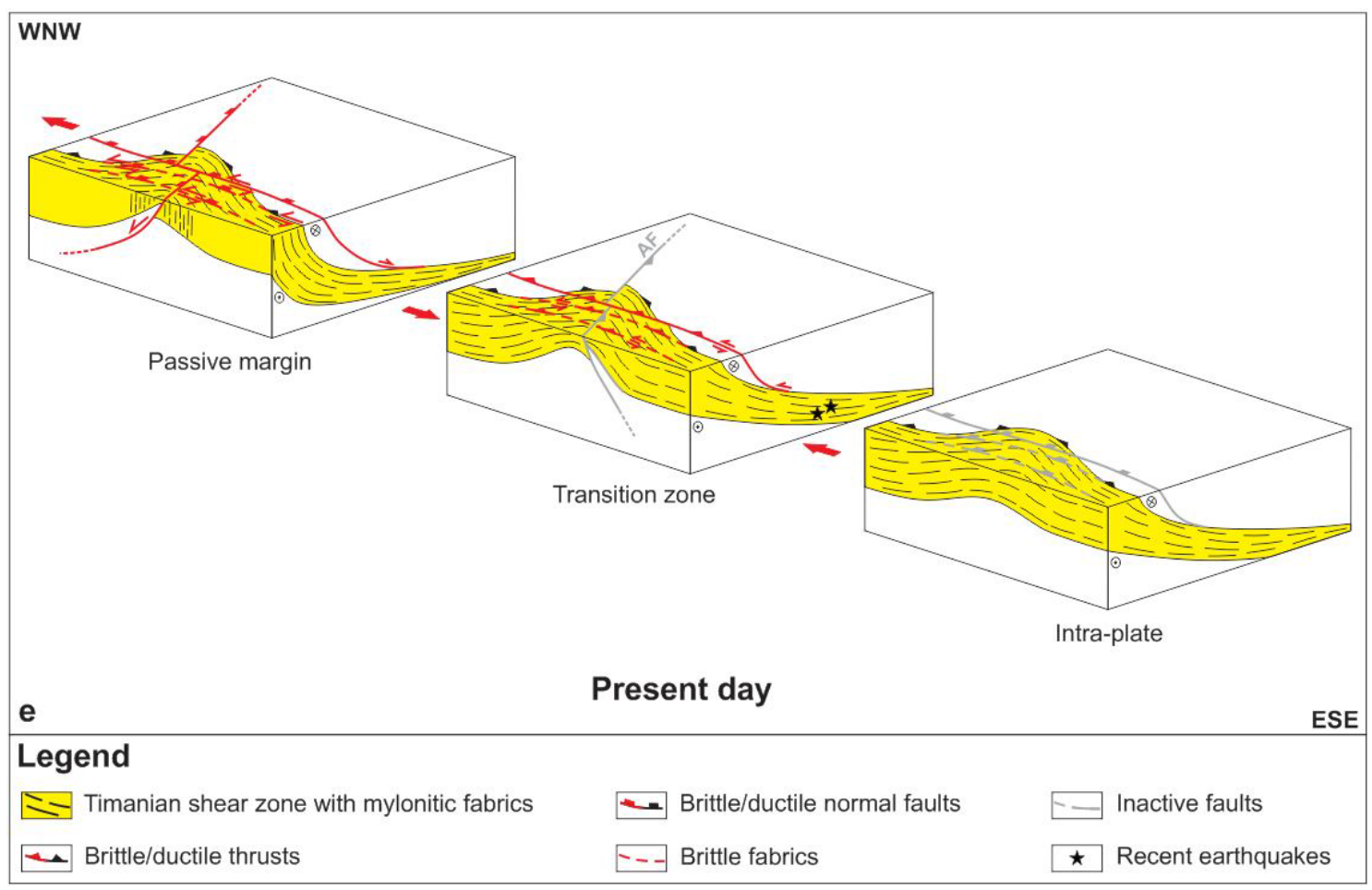

Figure 7. Tectonic evolution of Timanian thrust systems in eastern and southern Spitsbergen, Storfjorden, and the northern Norwegian Barents Sea including (a) top-SSW thrusting during the Timanian Orogeny, (b) reactivation as oblique-slip sinistral-reverse thrusts and offset by N-S-striking brittle thrust overprints (e.g., Agardhbukta Fault - AF) under E-W contraction during the Caledonian Orogeny, (c) reactivation as low-angle, brittle-ductile, normal-sinistral extensional detachments and overprinting by high-angle normal-sinistral brittle faults during Devonian-Carboniferous, late-post-Caledonian extensional collapse and rifting, (d) reactivation as brittle-ductile sinistral-reverse thrusts, overprinting by high-angle sinistral-reverse brittle thrusts, and mild offset by reactivated N-S-striking thrusts (e.g., Agardhbukta Fault AF) during E-W Eurekan contraction (note the absence of reactivation and overprinting away from the margin), and (e) renewed, recentongoing, sinistral-reverse reactivation and overprinting possibly due to ongoing magma extrusion and transform faulting (ridge-push?) in the Fram Strait, i.e., normal-sinistral along the Fram Strait passive margin and reverse-sinistral in the transition zone (e.g., Storfjorden and eastern Spitsbergen). Notice the relatively higher deformation intensity of Timanian thrusts at (paleo-)active and passive margins including sub-vertical geometry prone to accommodate lateral movement (e.g., Vimsodden-Kosibapasset Shear Zone in southern Spitsbergen) and milder reactivation-overprinting away from the margin where Timanian thrusts retained their low-angle geometry (e.g., eastern Spitsbergen, Storfjorden, and central Barents Sea). Folding of Timanian thrusts is also more gentle away from the margin (e.g., central Barents Sea, Olga and Ora basins).

ern Spitsbergen and the northwestern Norwegian Barents Sea (Fig. 5a-c) prior to the onset of E-W-oriented Caledonian contraction, it is probable that such large structures would have (at least partially) been reactivated and/or overprinted during subsequent tectonic events if suitably oriented. Under E-W contraction, WNW-ESE-striking, dominantly NNEdipping Timanian faults would be oriented at ca. $30^{\circ}$ to the direction of principal stress and therefore be suitable (according to Anderson's stress model) to reactivate and/or be overprinted with sinistral strike-slip movements. Such kinematics were recorded along the Vimsodden-Kosibapasset Shear Zone in Wedel Jarlsberg Land (Mazur et al., 2009) and within Hornsund (von Gosen and Piepjohn, 2001).

However, recent ${ }^{40} \mathrm{Ar}-{ }^{39} \mathrm{Ar}$ geochronological determinations on muscovite within this structure suggest that this structure formed during the Caledonian Orogeny (Faehn- rich et al., 2020). Nonetheless, the same authors also obtained Timanian ages (600-540 Ma) for (initial) movements along minor shear zones nearby and parallel to the Vimsodden-Kosibapasset Shear Zone. Since this large shear zone must have represented a major preexisting zone of weakness when Caledonian contraction initiated, it is highly probable that it was preferentially chosen to reactivate instead of minor shear zones. Thus, the Caledonian ages obtained along the Vimsodden-Kosibapasset Shear Zone most likely reflect complete resetting of the geochronometer along the shear zone due to large amounts of Caledonian reactivation-overprinting, while minor nearby shear zones preserved traces of initial Timanian deformation. This is also supported by observations in northern Norway suggesting that Timanian thrusts (e.g., TrollfjordenKomagelva Fault Zone) were reactivated as major strike-slip 
faults during the Caledonian Orogeny (Roberts, 1972; Herrevold et al., 2009; Rice 2014). This interpretation reconciles the strong differences in dipping angle and depth between the Kinnhøgda-Daudbjørnpynten fault zone and the Vimsodden-Kosibapasset Shear Zone. The former was located away from the Caledonian collision zone, essentially retained its initial moderately NNE-dipping Timanian geometry, and was deeply buried during the Phanerozoic, whereas the latter was intensely deformed, pushed into a sub-vertical position, and uplifted and exhumed to the surface because it was located near or within the Caledonian collision zone (Fig. 7b).

This further explains why Timanian faults were not reactivated exclusively as strike-slip faults despite being oriented sub-orthogonal (ca. $70^{\circ}$ ) to E-W Caledonian contraction. Portions of Timanian faults near the Caledonian collision zone were locally deformed into sub-vertical geometries suitable to accommodate lateral movement, whereas their counterparts retaining their moderate-low-angle dip away from the paleo-plate boundary were more prone to accommodate vertical movements (Fig. 7b). Moreover, lateral transport of rocks from the Caledonian collision front towards the inner portions of the Barents Sea in the east was hampered by rock units constituting the crust of the Barents Sea, northern Norway, northwestern Russia, and other adjacent areas. Hence, Caledonian $\mathrm{E}-\mathrm{W}$ contraction produced $\mathrm{N}-\mathrm{S}$-trending folds more easily (e.g., Figs. $3 b$ and e and $4 \mathrm{f}$ ), which extended almost all the way to Novaya Zemlya (Fig. 5), whereas partial strike-slip reactivation was restricted to areas proximal to the Caledonian collision front (e.g., western Spitsbergen; Majka et al., 2008; Mazur et al., 2009; Faehnrich et al., 2020; Ziemniak et al., 2020; Fig. 7b).

\subsubsection{Devonian-Carboniferous normal overprint-reactivation}

In Nordmannsfonna, the wedge shape of Devonian (Mississippian?) sedimentary strata in the hanging wall of the Kongsfjorden-Cowanodden fault zone suggests that the eastern portion of this thrust was reactivated as a gentlymoderately dipping extensional detachment (Fig. 6c) and thus that Devonian (-Mississippian?) strata in this area represent analogs to collapse deposits in northern Spitsbergen. The intrusion of west-dipping Devonian (-Mississippian?) dikes orthogonal to the eastern portion of the thrust system, i.e., orthogonal to extensional movements along the inverted east-dipping portion of the thrust (Figs. 3e and 6d), also supports this interpretation. Similar relationships were inferred in northwestern Spitsbergen, where Devonian collapse sediments were deposited along a N-S-trending Precambrian basement ridge bounded by a gently dipping, extensional mylonitic detachment (Braathen et al., 2018).

In Sassenfjorden, Storfjorden, and the northeastern Norwegian Barents Sea, listric brittle normal faults showing down-NNE offsets and syn-tectonic thickening within
Devonian-Carboniferous (-Permian?) sedimentary strata merge at depth with the uppermost part of NNE-dipping Timanian thrust systems like the Kongsfjorden-Cowanodden fault zone (Fig. 3a and d and Supplement S2c). This indicates that Timanian thrust systems were used as preexisting zones of weakness during late-post-orogenic collapse of the Caledonides in the Devonian-Carboniferous (Figs. 6c-e and $7 \mathrm{c})$.

The presence of the Kongsfjorden-Cowanodden fault zone in Storfjorden and below Edgeøya also explains the strong differences between the Paleozoic sedimentary successions penetrated by the Plurdalen-1 and Raddedalen-1 exploration wells (Bro and Shvarts, 1983; Harland and Kelly, 1997). Notably, the Plurdalen-1 well penetrated (at least) ca. $1600 \mathrm{~m}$ thick Devonian-Mississippian sedimentary rocks in the direct hanging wall of the Kongsfjorden-Cowanodden fault zone and related listric brittle overprints (Fig. 3a), whereas the interpretation of Bro and Shvarts (1983) suggests that the Raddedalen-1 well encountered thin (90-290 m thick) Mississippian strata overlying $(>2 \mathrm{~km})$ thick lower Paleozoic sedimentary rocks ca. $30 \mathrm{~km}$ farther northeast, i.e., away from the Kongsfjorden-Cowanodden fault zone and related overprints. The presence of thick Devonian sedimentary strata in the direct hanging wall of listric overprints of the Kongsfjorden-Cowanodden fault zone further supports late-post-Caledonian extensional reactivation-overprinting of NNE-dipping Timanian thrusts.

In central Spitsbergen, recently identified early DevonianMississippian normal faults formed along and overprintedreactivated major NNE-dipping ductile (mylonitic) shear zones and fabrics in Billefjorden (Koehl et al., 2021) and Sassenfjorden-Tempelfjorden (Koehl, 2021). These show sizes, geometries, and kinematics comparable to those of the Kongsfjorden-Cowanodden fault zone and are therefore, interpreted as the western continuation of this thrust system. The Devonian-Carboniferous extensional reactivationoverprinting of the Kongsfjorden-Cowanodden fault zone in central Spitsbergen explains the southward provenance of northwards-prograding sedimentary rocks of the uppermost Silurian-Lower Devonian Siktefjellet, Red Bay groups, and Wood Bay Formation as well as the enigmatic WNW-ESE trend of the southern boundary of the Devonian Graben in central-northern Spitsbergen (Gee and Moody-Stuart, 1966; Friend et al., 1966; Friend and Moody-Stuart, 1972; Murascov and Mokin, 1979; Friend et al., 1997; McCann, 2000; Dallmann and Piepjohn, 2020; Koehl et al., 2021).

\subsubsection{Mild Triassic overprint}

The Kongsfjorden-Cowanodden fault zone and associated overprints align with WNW-ESE- to NW-SE-striking normal faults in the onshore are of southern and southwestern Edgeøya in Kvalpynten, Negerpynten, and Øhmanfjellet (Osmundsen et al., 2014; Ogata et al., 2018). These faults display both listric and steep planar geometries in cross sec- 
tion and bound thickened syn-sedimentary growth strata in lowermost Upper Triassic sedimentary rocks of the Tschermakfjellet and De Geerdalen formations (Ogata et al., 2018; Smyrak-Sikora et al., 2020). The Norwegian Barents Sea and Svalbard are believed to have remained tectonically quiet throughout the Triassic apart from minor deep-rooted normal faulting in the northwestern Norwegian Barents Sea (Anell et al., 2013) and Uralides-related contraction in the (south)east (Müller et al., 2019). Hence, we propose that the progradation and accumulation of thick sedimentary deposits of the Triassic deltaic systems above the southeastward continuation of the Kongsfjorden-Cowanodden fault zone may have triggered minor tectonic adjustments resulting in the development of a system of small half-grabens over the thrust system. Alternatively or complementary, the deposition of thick Triassic deltaic systems may have locally accelerated compaction of sedimentary strata underlying the Tschermakjellet Formation in southern and southwestern Edgeøya, e.g., of the potential pre-Triassic syn-tectonic growth strata along the Kongsfjorden-Cowanodden fault zone and, thus facilitated the development of minor half-grabens within the Triassic succession along this thrust system.

\subsubsection{Eurekan reactivation-overprint}

In eastern Spitsbergen, the Agardhbukta Fault segment of the Lomfjorden fault zone truncates the KongsfjordenCowanodden fault zone with a major $>0.5 \mathrm{~s}$ (TWT) top-west reverse offset (Fig. 3e). The Agardhbukta Fault also mildly folds Pennsylvanian-Mesozoic sedimentary rocks and Cretaceous sills into a gentle upright (fault-propagation) fold with no major offset (Fig. $6 \mathrm{f}$ and g), which is supported by onshore field observations in eastern and northeastern Spitsbergen (Piepjohn et al., 2019). Mild folding of Mesozoic sedimentary rocks and of Cretaceous intrusions indicates that the Agardhbukta Fault was most likely mildly reactivated as a top-west thrust during the early Cenozoic Eurekan tectonic event (Figs. 6g and 7d).

Seismic data show that high-angle listric DevonianCarboniferous normal faults were mildly reactivated as reverse faults that propagated upwards and gently folded adjacent upper Paleozoic-Mesozoic (-Cenozoic?) sedimentary strata in the northwestern Norwegian Barents Sea, Storfjorden, and central-eastern Spitsbergen (Fig. 3a-c and Supplement S2), but not in the northeastern Norwegian Barents Sea (Figs. 3d and 7d). Since normal faults were not inverted in the east, it is probable that inversion of these faults in centraleastern Spitsbergen, Storfjorden, and the northwestern Norwegian Barents Sea first occurred during the Eurekan tectonic event in the early Cenozoic when Greenland collided with western Spitsbergen (Fig. 7d). This is also supported by the gently folded character of Devonian-Mesozoic (Cenozoic?) sedimentary successions in the west (Fig. 3a and c), whereas these successions are essentially flat-lying (i.e., undeformed) in the east (Fig. $3 b$ and d). Nevertheless, folding of the seafloor reflection in Storfjorden and the northwestern Norwegian Barents Sea suggests ongoing contractional deformation along several of these faults in the northwestern Norwegian Barents Sea and Storfjorden (Fig. 3a-c).

Major top-SSW mylonitic shear zones in SassenfjordenTempelfjorden and Billefjorden display early Cenozoic overprints including top-SSW duplexes in uppermost DevonianMississippian coals of the Billefjorden Group acting as a partial décollement along a major basement-seated listric brittle fault (Koehl, 2021; Supplement S2) and NNE-dipping brittle faults offsetting the east-dipping Billefjorden fault zone by hundreds of meters to several kilometers left-laterally (Koehl et al., 2021). Thus, the correlation of the KongsfjordenCowanodden fault zone with these top-SSW mylonitic shear zones in Sassenfjorden-Tempelfjorden and Billefjorden (see Fig. 1c for location) supports reactivation-overprinting of major NNE-dipping Timanian thrust systems as top-SSW, sinistral-reverse, oblique-slip thrusts in the early Cenozoic Eurekan tectonic event (Fig. 7d). Such correlation explains the NW-SE trend and the location of the northeastern boundary of the Central Tertiary Basin, which terminates just southwest of Sassenfjorden and Sassendalen in central Spitsbergen (Fig. $1 \mathrm{~b}$ and $\mathrm{c}$ ). It also explains the dominance of NW-SE- to WNW-ESE-striking faults within Cenozoic deposits of the Central Tertiary Basin (Livshits, 1965a), as well as the northwestwards provenance (Petersen et al., 2016) and northwards thinning of sediments deposited in the basin (Livshits, 1965b), which were probably sourced from uplifted areas in the hanging wall of the reactivated-overprinted thrust.

Noteworthy, Livshits (1965a) argued that the Central Tertiary Basin was bounded to the north by a major WNW-ESE-striking fault extending from Kongsfjorden to southern Billefjorden-Sassenfjorden where the NNEdipping Kongsfjorden-Cowanodden fault zone was mapped (present study; Supplement S2). This indicates that the Kongsfjorden-Cowanodden fault zone might extend west of Billefjorden and Sassenfjorden, potentially until Kongsfjorden (see Fig. 1c for location). Should this be the case, the Kongsfjorden-Cowanodden fault zone would coincide with a major terrane boundary in Svalbard, which was speculated to correspond to one or more regional WNW-ESE- to $\mathrm{N}-\mathrm{S}$-striking faults in earlier works, e.g., the Kongsvegen fault and Lapsdalen thrust (Harland and Horsfield, 1974), the Kongsvegen fault zone and/or the central-western fault zone (Harland and Wright, 1979), and the KongsfjordenHansbreen fault zone (Harland et al., 1993). The presence of a major (inherited Timanian) NNE-dipping, basement-seated fault zone in this area would explain the observed strong differences between Precambrian basement rocks in Svalbard's northwestern and southwestern terranes.

In southern Spitsbergen, von Gosen and Piepjohn (2001) and Bergh and Grogan (2003) suggested the presence of a WNW-ESE-striking, sinistral-reverse strike-slip fault in Hornsund based on a $1 \mathrm{~km}$ left-lateral offset of Devonian- 


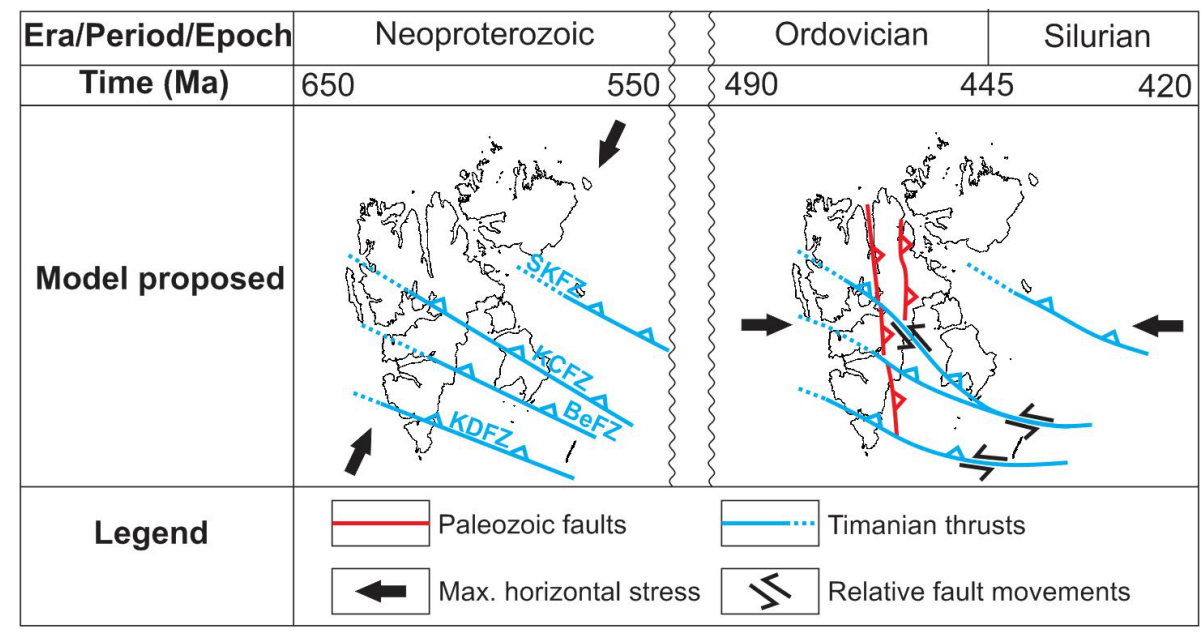

Figure 8. Paleogeographic reconstruction of the Svalbard Archipelago in the latest Neoproterozoic during the Timanian Orogeny and in the early to mid-Paleozoic during the Caledonian Orogeny according to the present study.

Carboniferous sedimentary successions and of the early Cenozoic Hyrnefjellet Anticline across the fjord. This fault is part of the Kinnhøgda-Daudbjørnpynten fault zone and was most likely reactivated-overprinted during Eurekan contraction-transpression in the early Cenozoic.

\subsubsection{Present-day tectonism}

Seismic data show that the seafloor reflection is folded and/or offset in a reverse fashion by high-angle brittle faults merging at depth with interpreted Timanian thrust systems in Storfjorden and just north of Bjørnøya in the northwestern Norwegian Barents (Figs. 3a and c, and 4h). This indicates that some of the Timanian thrust systems are still active at present and are reactivated and/or overprinted by reverse faults (Fig. 7e). A potential explanation for ongoing reactivation-overprinting is transfer of extensional tectonic stress in the Fram Strait as ridge-push tectonism through Spitsbergen and Storfjorden (Fig. 7e).

\subsection{Implication for plate tectonics reconstructions of the Barents Sea and Svalbard in the late Neoproterozoic-Paleozoic}

The presence of Timanian faults that are hundreds to thousands of kilometers long throughout the northern Norwegian Barents Sea and central and southwestern (and possibly northwestern?) Spitsbergen indicates that the northwestern, northeastern, and southwestern basement terranes of the Svalbard Archipelago were most likely already accreted together and attached to the Barents Sea, northern Norway, and northwestern Russia in the late Neoproterozoic (ca. $600 \mathrm{Ma}$ ). Svalbard's three terranes were previously thought to have been juxtaposed during the Caledonian and Ellesmerian orogenies through hundreds to thousands of kilometers of displacement along $\mathrm{N}-\mathrm{S}$-striking strike-slip faults presumed to be thousands of kilometers long like the Billefjorden fault zone (Harland, 1969; Harland et al., 1992; Labrousse et al., 2008; Fig. 2). The presence of laterally continuous (undisrupted) Timanian thrust systems that are hundreds to thousands of kilometers long from southwestern and central Spitsbergen to the northern Norwegian and Russian Barents Sea clearly shows that this is not possible (Fig. 8).

The continuous character of these thrust systems from potentially as far as onshore northwestern Russia through the Barents Sea and Svalbard precludes any major strike-slip displacement along N-S-striking faults such as the Billefjorden fault zone and Lomfjorden fault zone (as proposed by Harland et al., 1974, 1992; Labrousse et al., 2008; Fig. 2) as well as any hard-linked connection between these faults in Svalbard and analogous NE-SW-striking faults in Scotland in the Phanerozoic (as proposed by Harland, 1969). Instead, the present work suggests that the crust constituting the Barents Sea and the northeastern and southwestern basement terranes of Svalbard should be included as part of Baltica in future Arctic plate tectonics reconstructions for the late Neoproterozoic-Paleozoic period (i.e., until ca. $600 \mathrm{Ma}$; Fig. 8). It also suggests that the Caledonian suture zone, previously inferred to lie east of Svalbard in the Barents Sea (e.g., Gee and Teben'kov, 2004; Breivik et al., 2005; Barrère et al., 2011; Knudsen et al., 2019), may be located west of the presently described Timanian thrust systems, i.e., probably west of or in western Spitsbergen where Caledonian blueschist and eclogite metamorphism has been recorded in Precambrian basement rocks (Horsfield, 1972; Dallmeyer et al., 1990a; Ohta et al., 1995; Kosminska et al., 2014). 


\section{Conclusions}

1. Seismic data in the northern Norwegian Barents Sea and Svalbard reveal the existence of several systems of topSSW thrusts comprised of brittle-ductile thrusts, mylonitic shear zones, and associated SSW-verging folds that are hundreds to thousands of kilometers long, several kilometers thick, and appear to extend from onshore northwestern Russia to the northern Norwegian Barents Sea and to central and southwestern Spitsbergen. A notable structure is the Kongsfjorden-Cowanodden fault zone in Svalbard and the Norwegian Barents Sea, which likely merges with the Baidaratsky fault zone in the Russian Barents Sea and southern Novaya Zemlya. We interpret these thrust systems as being related to the Neoproterozoic Timanian Orogeny.

2. In the east (away from the Caledonian collision zone), these Timanian thrusts systems were folded into NNE-plunging folds, offset, and reactivated and/or overprinted by top-west, oblique-slip sinistral-reverse, brittle-ductile thrusts during subsequent Caledonian (e.g., Agardhbukta Fault segment of the Lomfjorden fault zone) and possibly during Eurekan contraction, and they are deeply buried. By contrast, in the west (near or within the Caledonian collision zone), Timanian thrusts were intensely deformed, pushed into sub-vertical positions, extensively overprinted, and exhumed to the surface.

3. In eastern Spitsbergen, a major NNE-dipping Timanian thrust system, the Kongsfjorden-Cowanodden fault zone, is crosscut by a swarm of Devonian (Mississippian?) dikes that intruded contemporaneous sedimentary strata deposited during extensional reactivation of the eastern portion of the thrust system as a low-angle extensional detachment during late-postCaledonian collapse.

4. Timanian thrust systems were overprinted by NNEdipping, brittle normal faults in the late Paleozoic during the collapse of the Caledonides and/or subsequent rifting in the Devonian-Carboniferous.

5. Timanian thrust systems and associated Caledonian and Devonian-Carboniferous brittle overprints (e.g., Agardhbukta Fault) in the northwestern Norwegian Barents Sea and Svalbard were mildly reactivated during the early Cenozoic Eurekan tectonic event, which resulted in minor folding and minor reverse offsets of DevonianMesozoic sedimentary strata and intrusions. Timanian thrusts and related overprints in the northeastern Norwegian Barents Sea were not reactivated during the Eurekan tectonic event.

6. The presence of Timanian thrust systems that are hundreds to thousands of kilometers long may suggest that the Barents Sea and Svalbard's three basement terranes were already attached to northern Norway and northwestern Russia in the late Neoproterozoic (ca. 600 Ma). If correct, a Timanian origin for these structures would preclude any major strike-slip movements along major $\mathrm{N}-\mathrm{S}$-striking faults like the Billefjorden and Lomfjorden fault zones in the Phanerozoic and imply that the Caledonian suture zone is located west of or in western Spitsbergen.

Data availability. For high-resolution versions of the figures and Supplement, the reader is referred to the open-access data repository DataverseNO (https://doi.org/10.18710/CE8RQH).

Supplement. The supplement related to this article is available online at: https://doi.org/10.5194/se-13-85-2022-supplement.

Author contributions. JBPK wrote the whole paper and interpreted the data (contribution: $45 \%$ ). CM contributed with significant input to rewriting, extensive scientific discussion, and figure editing (contribution: $35 \%$ ). IMA contributed with rewriting and extensive scientific discussion (contribution: $20 \%$ ).

Competing interests. The contact author has declared that neither they nor their co-authors have any competing interests.

Disclaimer. Publisher's note: Copernicus Publications remains neutral with regard to jurisdictional claims in published maps and institutional affiliations.

Acknowledgements. We thank the Norwegian Petroleum Directorate and the Federal Institute for Geosciences and Natural Resources (BGR) for granting access and allowing publication of seismic, magnetic, and gravimetric data in Svalbard and the Norwegian Barents Sea. Steffen Bergh, Winfried Dallmann, Jiri Konopasek, Mélanie Forien, Kate Waghorn (UiT The Arctic University of Norway in Troms $\emptyset$ ), Peter Klitzke (Federal Institute for Geosciences and Natural Resources - Germany), Anna Dichiarante (Norway Seismic Array), Rune Mattingsdal (Norwegian Petroleum Directorate), and Carmen Gaina (Centre for Earth Evolution and Dynamics, University of Oslo) are thanked for fruitful discussions.

Financial support. The present study was supported by the Research Council of Norway, the Troms $\emptyset$ Research Foundation, and six industry partners through the Research Centre for Arctic Petroleum Exploration (ARCEx; grant number 228107), the SEAMSTRESS project (grant number 287865), the Centre for Earth Evolution and Dynamics (CEED; grant number 223272), and the European Union's Horizon 2020 research and innovation pro- 
gram under the Marie Skłodowska-Curie grant (agreement number 101023439).

Review statement. This paper was edited by Susanne Buiter and reviewed by Anthony Doré, Jeremy Rimando, and Hamed Fazlikhani.

\section{References}

Aakvik, R.: Fasies analyse av Undre Karbonske kullførende sedimenter, Billefjorden, Spitsbergen, Ph.D. Thesis, University of Bergen, Bergen, Norway, 219 pp., 1981.

Andresen, A., Haremo, P., Swensson, E., and Bergh, S. G.: Structural geology around the southern termination of the Lomfjorden Fault Complex, Agardhdalen, east Spitsbergen, Norsk Geol. Tidsskr., 72, 83-91, 1992.

Anell, I., Braathen, A., Olaussen, S., and Osmundsen, P. T.: Evidence of faulting contradicts a quiescent northern Barents Shelf during the Triassic, First Break, 31, 67-76, 2013.

Anell, I. M., Braathen, A., and Olaussen, S.: Regional constraints of the Sørkapp Basin: A Carboniferous relic or a Cretaceous depression, Mar. Petrol. Geol., 54, 123-138, 2014.

Anell, I. M., Faleide, J. I., and Braathen, A.: Regional tectonosedimentary development of the highs and basins of the northwestern Barents Shelf, Norsk Geol. Tidsskr., 96, 27-41, 2016.

Arbaret, L. and Burg, J.-P.: Complex flow in lowest crustal, anastomosing mylonites: Strain gradients in a Kohistan gabbro, northern Pakistan, J. Geophys. Res., 108, https://doi.org/10.1029/2002JB002295, 2467, 2003.

Barrère, C., Ebbing, J., and Gernigon, L.: Offshore prolongation of Caledonian structures and basement characterization in the western Barents Sea from geophysical modelling, Tectonophysics, 470, 71-88, 2009.

Barrère, C., Ebbing, J., and Gernigon, L.: 3-D density and magnetic crustal characterization of the southwestern Barents Shelf: implications for the offshore prolongation of the Norwegian Caledonides, Geophys. J. Int., 184, 1147-1166, 2011.

Bergh, S. G. and Grogan, P.: Tertiary structure of the SørkappHornsund Region, South Spitsbergen, and implications for the offshore southern continuation of the fold-thrust Belt, Norsk Geol. Tidsskr., 83, 43-60, 2003.

Boyer, S. E. and Elliott, D.: Thrust Systems, AAPG Bull., 66, 11961230, 1982.

Braathen, A., Bælum, K., Maher Jr., H. D., and Buckley, S. J.: Growth of extensional faults and folds during deposition of an evaporite-dominated half-graben basin; the Carboniferous Billefjorden Trough, Svalbard, Norsk Geol. Tidsskr., 91, 137-160, 2011.

Braathen, A., Osmundsen, P. T., Maher, H., and Ganerød, M.: The Keisarhjelmen detachment records Silurian-Devonian extensional collapse in Northern Svalbard, Terra Nova, 30, 34-39, 2018.

Breivik, A. J., Mjelde, R., Grogan, P., Shimamura, H., Murai, Y., and Nishimura, Y.: Caledonide development offshore-onshore Svalbard based on ocean bottom seismometer, conventional seismic, and potential field data, Tectonophysics, 401, 79-117, 2005.

Bro, E. G. and Shvarts, V. H.: Processing results from drill hole Raddedalen-1, Edge Island, Spitzbergen Archipelago, All-
Russian Research Institute for Geology and Mineral Resources of the World Ocean, St. Petersburg, Pangaea, Report 5750, 1983.

Cawood, P. A., McCausland, P. J. A., and Dunning, G. R.: Opening Iapetus: Constraints from the Laurentian margin in Newfoundland, Geol. Soc. Am. Bull., 113, 443-453, 2001.

Chalmers, J. A. and Pulvertaft, T. C. R.: Development of the continental margins of the Labrador Sea: a review, in: Non-Volcanic Rifting of Continental Margins: A Comparison of Evidence from Land and Sea, edited by: Wilson, R. C. L., Taylor, R. B., and Froitzheim, N., Geol. Soc. Spec. Publ., 187, 77-105, 2001.

Cocks, L. R. M. and Torsvik, T. H.: Baltica from the late Precambrian to mid-Palaeozoic times: The gain and loss of a terrane's identity, Earth-Sci. Rev., 72, 39-66, 2005.

Colombu, S., Cruciani, G., Fancello, D., Franceschelli, M., and Musumeci, G.: Petrophysical properties of a graniteprotomylonite-ultramylonite sequence: insight from the Monte Grighini shear zone, central Sardinia, Italy, Eur. J. Mineral, 27, 471-486, 2015.

Corfu, F., Andersen, T. B., and Gasser, D.: The Scandinavian Caledonides: main features, conceptual advances and critical questions, in: New Perspectives on the Caledonides of Scandinavia and Related Areas, edited by: Corfu, F., Gasser, D., and Chew, D. M., Geol. Soc. Spec. Publ., 390, 9-43, 2014.

Cutbill, J. L. and Challinor, A.: Revision of the Stratigraphical Scheme for the Carboniferous and Permian of Spitsbergen and Bjørnøya, Geol. Mag., 102, 418-439, 1965.

Cutbill, J. L., Henderson, W. G., and Wright, N. J. R.: The Billefjorden Group (Early Carboniferous) of central Spitsbergen, Norsk Polarinst. Skri., 164, 57-89, 1976.

Dallmann, W. K.: Geoscience Atlas of Svalbard, Norsk Polarinstitutt, Troms $\varnothing$, Norway, Rapportserie nr. 148, 2015.

Dallmann, W. K. and Krasil'scikov, A. A.: Geological map of Svalbard 1:50,000, sheet D20G Bjørnøya, Norsk Polarinst. Temakart, Troms $\varnothing$, Norway, 27, 1996.

Dallmann, W. K. and Piepjohn, K.: The structure of the Old Red Sandstone and the Svalbardian Orogenic Event (Ellesmerian Orogeny) in Svalbard, Norg. Geol. Unders. B., Spec. Publ., 15, 106 pp., 2020.

Dallmann, W. K., Andresen, A., Bergh, S. G., Maher Jr., H. D. and Ohta, Y.: Tertiary fold-and-thrust belt of Spitsbergen Svalbard, Norsk Polarinstitutt Meddelelser 128, 51 pp., 1993.

Dallmeyer, R. D., Peucat, J. J., Hirajima, T., and Ohta, Y.: Tectonothermal chronology within a blueschist-eclogite complex, west-central Spitsbergen, Svalbard: Evidence from ${ }^{40} \mathrm{Ar} /{ }^{39} \mathrm{Ar}$ and Rb-Sr mineral ages, Lithos, 24, 291-304, 1990a.

Dallmeyer, R. D., Peucat, J. J., and Ohta, Y.: Tectonothermal evolution of contrasting metamorphic complexes in northwest Spitsbergen (Biskayerhalvøya): Evidence from ${ }^{40} \mathrm{Ar} /{ }^{39} \mathrm{Ar}$ and $\mathrm{Rb}-\mathrm{Sr}$ mineral ages, Geol. Soc. Am. Bull., 102, 653-663, 1990b.

Dewey, J. F. and Strachan, R. A.: Changing Silurian-Devonian relative plate motion in the Caledonides: sinistral transpression to sinistral transtension, J. Geol. Soc. London, 160, 219-229, 2003.

Drachev, S. S.: Fold belts and sedimentary basins of the Eurasian Arctic, Arktos, 2, 21, https://doi.org/10.1007/s41063-015-00148, 2016.

Drachev, S. S., Malyshev, N. A., and Nikishin, A. M.: Tectonic history and petroleum geology of the Russian Arctic Shelves: an overview, Petrol. Geol. Conf. Ser., 7, 591-619, 2010. 
Dumais, M.-A. and Brönner, M.: Revisiting Austfonna, Svalbard, with potential field methods - a new characterization of the bed topography and its physical properties, The Cryosphere, 14, 183197, https://doi.org/10.5194/tc-14-183-2020, 2020.

Eldholm, O. and Ewing, J.: Marine Geophysical Survey in the Southwestern Barents Sea, J. Geophys. Res., 76, 3832-3841, 1971.

Engen, Ø., Faleide, J. I., and Dyreng, T. K.: Opening of the Fram Strait gateway: A review of plate tectonic constraints, Tectonophysics, 450, 51-69, 2008.

Estrada, S., Tessensohn, F., and Sonntag, B.-L.: A Timanian islandarc fragment in North Greenland: The Midtkap igneous suite, J. Geodyn., 118, 140-153, 2018.

Evdokimov, A. N., Burnaeva, M. Yu., Radina, E. S., and Sirotkin, A. N.: The First Find of Kimberlitic Accessory Minerals in MaficUltramafic Dikes in Spitsbergen, Doklady Earth Sciences, 407, 275-279, 2006,

Faehnrich, K., Majka, J., Schneider, D., Mazur, S., Manecki, M., Ziemniak, G., Wala, V. T., and Strauss, J. V.: Geochronological constraints on Caledonian strike-slip displacement in Svalbard, with implications for the evolution of the Arctic, Terra Nova, 32, 290-299, 2020.

Fortey, R. A. and Bruton, D. L.: Lower Ordovician trilobites of the Kirtonryggen Formation, Spitsbergen, ossils and Strata, 59, Wiley Blackwell, Hoboken, New Jersey, United States, 120 pp., 2013.

Fountain, D. M., Hurich, C. A., and Smithson, S. B.: Seismic relectivity of mylonite zones in the crust, Geology, 12, 195-198, 1984.

Friend, P. F. and Moody-Stuart, M.: Sedimentation of the Wood Bay Formation (Devonian) of Spitsbergen: Regional analysis of a late orogenic basin, Norsk Polarinst. Skri., 157, 1-80, 1972.

Friend, P. F., Heintz, N., and Moody-Stuart, M.: New unit terms for the Devonian of Spitsbergen and a new stratigraphical scheme for the Wood Bay Formation, Polarinst. Årbok, 1965, 59-64, 1966.

Friend, P. F., Harland, W. B., Rogers, D. A., Snape, I., and Thornley, R. S.: Late Silurian and Early Devonian stratigraphy and probable strike-slip tectonics in northwestern Spitsbergen, Geol. Mag., 134, 459-479, 1997.

Gasser, D.: The Caledonides of Greenland, Svalbard and other Arctic areas: status of research and open questions, in: New Perspectives on the Caledonides of Scandinavia and Related Areas, edited by: Corfu, F., Gasser, D., and Chew, D. M., Geol. Soc. Spec. Publ., 390, 93-129, 2014.

Gee, D. G. and Moody-Stuart, M.: The base of the Old Red Sandstone in central north Haakon VII Land, Vestspitsbergen, Polarinst. Årbok, 1964, 57-68, 1966.

Gee, D. G. and Pease, V.: The Neoproterozoic Timanide Orogen of eastern Baltica: introduction, in: The Neoproterozoic Timanide Orogen of eastern Baltica, edited by: Gee, D. G. and Pease, V., Geol. Soc. Mem., 30, 1-3, 2004.

Gee, D. G. and Teben'kov, A. M.: Svalbard: a fragment of the Laurentian margin, in: The Neoproterozoic Timanide Orogen of eastern Baltica, edited by: Gee, D. G. and Pease, V., Geol. Soc. Mem., 30, 191-206, 2004.

Gee, D. G., Björklund, L., and Stølen, L.-K.: Early Proterozoic basement in Ny Friesland-implications for the Caledonian tectonics of Svalbard, Tectonophysics, 231, 171-182, 1994.

Gee, D. G., Fossen, H., Henriksen, N., and Higgins, A. K.: From the Early Paleozoic Platforms of Baltica and Laurentia to the Cale- donide Orogen of Scandinavia and Greenland, Episodes, 31, 44 51,2008 .

Gernigon, L. and Brönner, M.: Late Palaeozoic architecture and evolution of the southwestern Barents Sea: insights from a new generation of aeromagnetic data, J. Geol. Soc. London, 169, 449459, 2012.

Gernigon, L., Brönner, M., Roberts, D., Olesen, O., Nasuti, A., and Yamasaki, T.: Crustal and basin evolution of the southwestern Barents Sea: From Caledonian orogeny to continental breakup, Tectonics, 33, 347-373, 2014.

Gernigon, L., Brönner, M., Dumais, M.-A., Gradmann, S., Grønlie, A., Nasuti, A., and Roberts, D.: Basement inheritance and salt structures in the SE Barents Sea: Insights from new potential field data, J. Geodyn., 119, 82-106, 2018.

Gjelberg, J. G.: Lower - Mid Carboniferous strata Spitsbergen, Ph.D. Thesis, University of Bergen, Bergen, Norway, Part III, 185 pp., 1983.

Griffin, W. L., Nikolic, N., O'Reilly, S. Y., and Pearson, N. J.: Coupling, decoupling and metasomatism: Evolution of crust-mantle relationships beneath NW Spitsbergen, Lithos, 149, 115-135, 2012.

Gudlaugsson, S. T., Faleide, J. I., Johansen, S. E., and Breivik, A. J.: Late Palaeozoic structural development of the South-western Barents Sea, Mar. Petrol. Geol., 15, 73-102, 1998.

Guise, P. G. and Roberts, D.: Devonian ages from ${ }^{40} \mathrm{Ar} /{ }^{39} \mathrm{Ar}$ dating of plagioclase in dolerite dykes, eastern Varanger Peninsula, North Norway, Nor. Geol. Unders., 440, 27-37, 2002.

Haremo, P. and Andresen, A.: Tertiary décollements thrusting and inversion structures along Billefjorden and Lomfjorden Fault Zones, East Central Spitsbergen, in: Structural and Tectonic Modelling and its Apllication to Petroleum Geology, edited by: Larsen, R. M., Brekke, H., Larsen, B. T., and Talleraas, E., NPF Sp. Publ., 1, 481-494, 1992.

Harland, W. B.: Contribution of Spitsbergen to understanding of tectonic evolution of North Atlantic region, AAPG Memoir., 12, 817-851, 1969.

Harland, W. B. and Horsfield, W. T.: West Spitsbergen Orogen, in: Mesozoic-Cenozoic Orogenic Belts, data for Orogenic Studies, J. Geol. Soc. London, Spec. Publ., 4, 747-755, 1974.

Harland, W. B. and Kelly, S. R. A.: Eastern Svalbard Platform, in: Geology of Svalbard, edited by: Harland, W. B., Geol. Soc. Mem., 17, 75-95, 1997.

Harland, W. B. and Wright, N. J. R.: Alternative hypothesis for the pre-Carboniferous evolution of Svalbard, Norsk Polarinst. Skri., 167, 89-117, 1979.

Harland, W. B., Cutbill, L. J., Friend, P. F., Gobbett, D. J., Holliday, D. W., Maton, P. I., Parker, J. R., and Wallis, R. H.: The Billefjorden Fault Zone, Spitsbergen - the long history of a major tectonic lineament, Norsk Polarinst. Skri., 161, 1-72, 1974.

Harland, W. B., Scott, R. A., Auckland, K. A., and Snape, I.: The Ny Friesland Orogen, Spitsbergen, Geol. Mag., 129, 679-708, 1992.

Harland, W. B., Hambrey, M. J., and Waddams, P.: Vendian geology of Svalbard, Norsk Polarinst. Skri., 193, 1-150, 1993.

Hassaan, M.: Evaporite-influenced rift basins and salt tectonics in the southeastern Norwegian Barents Sea, Ph.D. Thesis, University of Oslo, Oslo, Norway, 305 pp., 2021.

Hassaan, M., Faleide, J. I., Gabrielsen, R. H., and Tsikalas, F.: Carboniferous graben structures, evaporite accumula- 
tions and tectonic inversion in the southeastern Norwegian Barents Sea, Mar. Petrol. Geol., 112, 104038, https://doi.org/10.1016/j.marpetgeo.2019.104038, 2020a.

Hassaan, M., Faleide, J. I., Gabrielsen, R. H., and Tsikalas, F.: Architecture of the evaporite accumulation and salt structures dynamics in Tiddlybanken Basin, southeastern Norwegian Barents Sea, Basin Res., 33, 91-117, 2020 b.

Hassaan, M., Faleide, J. I., Gabrielsen, R. H., and Tsikalas, F.: Effects of basement structures and Carboniferous basin configuration on evaporite distribution and the development of salt structures in Nordkapp Basin, Barents Sea - Part I, Basin Res., 33, 2474-2499, 2021.

Herrevold, T., Gabrielsen, R. H., and Roberts, D.: Structural geology of the southeastern part of the Trollfjorden-Komagelva Fault Zone, Varanger Peninsula, Finnmark, North Norway, Norw. J. Geol., 89, 305-325, 2009.

Horsfield, W. T.: Glaucophane schists of Caledonian age from Spitsbergen, Geol. Mag., 109, 29-36, 1972.

Hurich, C. A., Smithson, S. B., Fountain, D. M., and Humphreys, M. C.: Seismic evidence of mylonite reflectivity and deep structure in the Kettle dome metamorphic core complex, Washington, Geology, 13, 577-580, 1985.

Jakobsson, M., Mayer, L., Coackley, B., Dowdeswell, J. A., Forbes, S., Fridman, B., Hodnesdal, H., Noormets, R., Pedersen, R., Rebesco, M., Schenke, H. W., Zarayskaya, Y., Accettella, D., Armstrong, A., Anderson, R. M., Bienhoff, P., Camerlenghi, A., Church, I., Edwards, M., Gardner, J. V., Hall, J. K., Hell, B., Hestvik, O., Kristoffersen, Y., Marcussen, C., Mohammad, R., Mosher, D., Nghiem, S. V., Pedrosa, M. T., Travaglini, P. G., and Weatherall, P.: The International Bathymetric Chart of the Arctic Ocean (IBCAO) Version 3.0, Geophys. Res. Lett., 39, L12609, https://doi.org/10.1029/2012GL052219, 2012.

Johansen, S. E., Ostisty, B. K., Birkeland, Ø., Fedorovsky, Y. F., Martirosjan, V. N., Bruun Christensen, O., Cheredeev, S. I., Ignatenko, E. A., and Margulis, L. S.: Hydrocarbon potential in the Barents Sea region: play distribution and potential, in: Arctic Geology and Petroleum Potential, edited by: Vorren, T. O., Bergsager, E., Dahl-Stamnes, Ø. A., Holter, E., Johansen, B., Lie, E., and Lund, T. B., NPF Sp. Publ., 2, 273-320, 1992.

Johansson, Å., Larionov, A. N., Gee, D. G., Ohta, Y., Tebenkov, A. M., and Sandelin, S.: Greenvillian and Caledonian tectono-magmatic activity in northeasternmost Svalbard, in: The Neoproterozoic Timanide Orogen of Eastern Baltica, edited by: Gee, D. G. and Pease, V., Geol. Soc. Mem., 30, 207-232, 2004.

Johansson, Å., Gee, D. G., Larionov, A. N., Ohta, Y., and Tebenkov, A. M.: Greenvillian and Caledonian evolution of eastern Svalbard - a tale of two orogenies, Terra Nova, 17, 317-325, 2005.

Kairanov, B., Escalona, A., Mordascova, A., Sliwinska, K., and Suslova, A.: Early Cretaceous tectonostratigraphy evolution of the north central Barents Sea, J. Geodyn., 119, 183-198, 2018.

Klitzke, P., Franke, D., Ehrhardt, A., Lutz, R., Reinhardt, L., Heyde, I., and Faleide, J. I.: The Palaeozoic Evolution of the Olga Basin Region, Northern Barents Sea: A Link to the Timanian Orogeny, Geochem. Geophy. Geosy., 20, 614-629, 2019.

Knudsen, C., Gee, D. G., Sherlock, S. C., and Yu, L.: Caledonian metamorphism of metasediments from Franz Josef Land, GFF, 141, 295-307, 2019.
Koehl, J.-B. P.: Impact of Timanian thrusts on the Phanerozoic tectonic history of Svalbard, Keynote lecture, EGU General Assembly, 3-8 May 2020, Vienna, Austria, 2020.

Koehl, J.-B. P.: Early Cenozoic Eurekan strain partitioning and decoupling in central Spitsbergen, Svalbard, Solid Earth, 12, 10251049, https://doi.org/10.5194/se-12-1025-2021, 2021.

Koehl, J.-B. P.: Caledonian reactivation of Timanian structures onshore-offshore northern Norway, in prep., 2022.

Koehl, J.-B. P. and Muñoz-Barrera, J. M.: From widespread Mississippian to localized Pennsylvanian extension in central Spitsbergen, Svalbard, Solid Earth, 9, 1535-1558, https://doi.org/10.5194/se-9-1535-2018, 2018.

Koehl, J.-B. P., Bergh, S. G., Henningsen, T., and Faleide, J. I.: Middle to Late Devonian-Carboniferous collapse basins on the Finnmark Platform and in the southwesternmost Nordkapp basin, SW Barents Sea, Solid Earth, 9, 341-372, https://doi.org/10.5194/se9-341-2018, 2018.

Koehl, J.-B. P., Bergh, S. G., Osmundsen, P. T., Redfield, T., Indrevær, K., Lea. H., and Berg $\varnothing$, E.: Late DevonianCarboniferous faulting and controlling structures and fabrics in NW Finnmark, Norw. J. Geol., 99, 1-40, 2019.

Koehl, J.-B. P., Allaart, L., and Noormets, R.: DevonianCarboniferous extension and Eurekan inversion along a major system of WNW-ESE-striking faults controlled by inherited basement fabrics in Billefjorden, in review, 2021.

Korago, E. A., Kovaleva, G. N., Lopatin, B. G., and Orgo, V. V.: The Precambrian rocks of Novaya Zemlya, in: The Neoproterozoic Timanide Orogen of Eastern Baltica, edited by: Gee, D. G. and Pease, V., Geol. Soc. Mem., 30, 135-143, 2004.

Kosminska, K., Majka, J., Mazur, S., Krumbholz, M., Klonowska, I., Manecki, M., Czerny, J., and Dwornik, M.: Blueschist facies metamorphism in Nordenskiöld Land of west-central Svalbard, Terra Nova, 26, 377-386, 2014.

Kostyuchenko, A., Sapozhnikov, R., Egorkin, A., Gee, D. G., Berzin, R., and Solodilov, L.: Crustal structure and tectonic model of northeastern Baltica, based on deep seismic and potential field data, in: European Lithosphere Dynamics, edited by: Gee, D. G. and Stephenson, R. A., Geol. Soc. Mem., 32, 521539, 2006.

Labrousse, L., Elvevold, S., Lepvrier, C., and Agard, P.: Structural analysis of high-pressure metamorphic rocks of Svalbard: Reconstructing the early stages of the Caledonian orogeny, Tectonics, 27, 22 pp., https://doi.org/10.1029/2007TC002249, 2008.

Lamar, D. L. and Douglass, D. N.: Geology of an area astride the Billefjorden Fault Zone, Northern Dicksonland, Spitsbergen, Svalbard, Norsk Polarinst. Skri., 197, 1-44, 1995.

Lamar, D. L., Reed, W. E., and Douglass, D. N.: Billefjorden fault zone, Spitsbergen: Is it part of a major Late Devonian transform?, Geol. Soc. Am. Bull. , 97, 1083-1088, 1986.

Larssen, G. B., Elvebakk, G., Henriksen, L. B., Kristensen, S.-E., Nilsson, I., Samuelsberg, T. J., Svånå, T. A., Stemmerik, L., and Worsley, D.: Upper Palaeozoic lithostratigraphy of the Southern part of the Norwegian Barents Sea, Norg. Geol. Unders. B., 444, 3-43, 2005.

Lasabuda, A., Laberg, J. S., Knutsen, S.-M., and Safronova, P.: Cenozoic tectonostratigraphy and pre-glacial erosion: A massbalance study of the northwestern Barents Sea margin, Norwegian Arctic, J. Geodyn., 119, 149-166, 2018. 
Lippard, S. J. and Prestvik, T.: Carboniferous dolerite dykes on Magerøy: new age determination and tectonic significance, Norsk Geol. Tidsskr., 77, 159-163, 1997.

Livshits, Yu. Ya.: Tectonics of Central Vestspitsbergen, in: Geology of Spitsbergen, edited by: Sokolov, V. N., National Lending Library of Science and Technology, Boston Spa., Yorkshire, UK, 59-75, 1965a.

Livshits, Yu. Ya.: Paleogene deposits of Nordenskiöld Land, Vestspitsbergen, in: Geology of Spitsbergen, edited by: Sokolov, V. N., National Lending Library of Science and Technology, Boston Spa., Yorkshire, UK, 193-215, 1965 b.

Lopatin, B. G., Pavlov, L. G., Orgo, V. V., and Shkarubo, S. I.: Tectonic Structure of Novaya Zemlya, Polarforschung, 69, 131-135, 2001.

Lorenz, H., Pystin, A. M., Olovyanishnikov, V. G., and Gee, D. G.: Neoproterozoic high-grade metamorphism of the Kanin Peninsula, Timanide Orogen, northern Russia, in: The Neoproterozoic Timanide Orogen of Eastern Baltica, edited by: Gee, D. G. and Pease, V., Geol. Soc. Mem., 30, 59-68, 2004.

Lorenz, H., Männik, P., Gee, D., and Proskurnin, V.: Geology of the Severnaya Zemlya Archipelao and the North Kara Terrane in the Russian high Arctic, Int. J. Earth Sci., 97, 519-547, 2008.

Lowell, J. D.: Spitsbergen tertiary Orogenic Belt and the Spitsbergen Fracture Zone, Geol. Soc. Am. Bull., 83, 3091-3102, 1972.

Lyberis, N. and Manby, G.: Continental collision and lateral escape deformation in the lower and upper crust: An example from Caledonide Svalbard, Tectonics, 18, 40-63, 1999.

Majka, J. and Kosminska, K.: Magmatic and metamorphic events recorded within the Southwestern Basement Province of Svalbard, Arktos, 3, 5, https://doi.org/10.1007/s41063-017-0034-7, 2017.

Majka, J., Mazur, S., Manecki, M., Czerny, J., and Holm, D. K.: Late Neoproterozoic amphibolite-facies metamorphism of a preCaledonian basement block in southwest Wedel Jarlsberg Land, Spitsbergen: new evidence from U-Th-Pb dating of monazite, Geol. Mag., 145, 822-830, 2008.

Majka, J., Larionov, A. N., Gee, D. G., Czerny, J., and Prsek, J.: Neoproterozoic pegmatite from Skoddefjellet, Wedel Jarlsberg Land, Spitsbergen: Additional evidence for c. $640 \mathrm{Ma}$ tectonothermal event in the Caledonides of Svalbard, Polish Polar Res., 33, 1-17, 2012.

Majka, J., De'eri-Shlevin, Y., Gee, D. G., Czerny, J., Frei, D., and Ladenberger, A.: Torellian (c. $640 \mathrm{Ma}$ ) metamorphic overprint of Tonian (c. $950 \mathrm{Ma}$ ) basement in the Caledonides of southwestern Svalbard, Geol. Mag., 151, 732-748, 2014.

Manby, G. M. and Lyberis, N.: Tectonic evolution of the Devonian Basin of northern Spitsbergen, Norsk Geol. Tidsskr., 72, 7-19, 1992.

Manby, G. M., Lyberis, N., Chorowicz, J., and Thiedig, F.: PostCaledonian tectonics along the Billefjorden fault zone, Svalbard, and implications for the Arctic region, Geol. Soc. Am. Bul., 105, 201-216, 1994.

Manecki, M., Holm, D. K., Czerny, J., and Lux, D.: Thermochronological evidence for late Proterozoic (Vendian) cooling in southwest Wedel Jarlsberg Land, Spitsbergen, Geol. Mag., 135, 63-69, 1998.

Marello, L., Ebbing, J., and Gernigon, L.: Magnetic basement study in the Barents Sea from inversion and forward modelling, Tectonophysics, 493, 153-171, 2010.
Marello, L., Ebbing, J., and Gernigon, L.: Basement inhomogeneities and crustal setting in the Barents Sea from a combined 3D gravity and magnetic model, Geophys. J. Int., 193, 557-584, 2013.

Mazur, S., Czerny, J., Majka, J., Manecki, M., Holm, D., Smyrak, A., and Wypych, A.: A strike-slip terrane boundary in Wedel Jarlsberg Land, Svalbard, and its bearing on correlations pf SW Spitsbergen with the Pearya terrane and Timanide belt, J. Geol. Soc. London, 166, 529-544, 2009.

McCann, A. J.: Deformation of the Old Red Sandstone of NW Spitsbergen; links to the Ellesmerian and Caledonian orogenies, in: New Perspectives on the Old Red Sandstone, edited by: Friends, P. F., and Williams, B. P. J., Geol. Soc. Spec. Publ., 180, 567-584, 2000.

Merdith, A. S., Williams, S. E., Collins, A. S., Tetley, M. G., Mulder, J. A., Blades, M. L., Young, A., Armistead, S. E., Cannon, J., Zahirovic, S., and Müller, R. D.: Extending fullplate tectonic models into deep time: Linking the Neoproterozoic and the Phanerozoic, Earth-Sci. Rev., 214, 103477, https://doi.org/10.1016/j.earscirev.2020.103477, 2021.

Müller, R., Klausen, T. G., Faleide, J. I., Olaussen, S., Eide, C. H., and Suslova, A.: Linking regional unconformities in the Barents Sea to compression-induced forebulge uplift at the TriassicJurassic transition, Tectonophysics, 765, 35-51, 2019.

Murascov, L. G. and Mokin, Ju. I.: Stratigraphic subdivision of the Devonian deposits of Spitsbergen, Norsk Polarinst. Skri., 167, 249-261, 1979.

Nasuti, A., Roberts, D., and Gernigon, L.: Multiphase mafic dykes in the Caledonides of northern Finnmark revealed by a new highresolution aeromagnetic dataset, Norw. J. Geol., 95, 251-263, 2015.

Norton, M. G., McClay, K. R., and Way, N. A.: Tectonic evolution of Devonian basins in northern Scotland and southern Norway, Norsk Geol. Tidsskr., 67, 323-338, 1987.

Oakey, G. N. and Chalmers, J. A.: A new model for the Paleogene motion of Greenland relative to North America: Plate reconstructions of the Davis Strait and Nares Strait regions between Canada and Greenland, J. Geophys. Res., 117, B10401, https://doi.org/10.1029/2011JB008942, 2012.

Ogata, K., Mulrooney, M. J., Braathen, A., Maher, H., Osmundsen, P. T., Anell, I., Smyrak-Sikora, A. A., and Balsamo, F.: Architecture, deformation style and petrophysical properties of growth fault systems: the Late Triassic deltaic succession of southern Edgeøya (East Svalbard), Basin Res., 30, 1042-1073, 2018.

Ohta, Y., Dallmeyer, R. D., and Peucat, J. J.: Caledonian terranes in Svalbard, Geol. Soc. Am. S., 230, 1-15, 1989.

Ohta, Y., Krasil'scikov, A. A., Lepvrier, C., and Teben'kov, A. M.: Northern continuation of Caledonian high-pressure metamorphic rocks in central-western Spitsbergen, Polar Res., 14, 303-315, 1995.

Olovyanishshnikov, V. G., Roberts, D., and Siedlecka, A.: Tectonics and Sedimentation of the Meso- to Neoproterozoic TimanVaranger Belt along the Northeastern Margin of Baltica, Polarforschung, 68, 267-274, 2000.

Osmundsen, P-T., Braathen, A., Rød, R. S., and Hynne, I. B.: Styles of normal faulting and fault-controlled sedimentation in the Triassic deposits of Eastern Svalbard, Norwegian Petroleum Directorate Bulletin, 10, 61-79, 2014. 
Petersen, T. G., Thomsen, T. B., Olaussen, S., and Stemmerik, L.: Provenance shifts in an evolving Eurekan foreland basin: the Tertiary Central Basin, Spitsbergen, J. Geol. Soc. London, 173, 634648, 2016.

Peucat, J.-J., Ohta, Y., Gee, D. G., and Bernard-Griffiths, J.: U$\mathrm{Pb}, \mathrm{Sr}$ and $\mathrm{Nd}$ evidence for Grenvillian and latest Proterozoic tectonothermal activity in the Spitsbergen Caledonides, Arctic Ocean, Lithos, 22, 275-285, 1989.

Phillips, T., Jackson, C. A-L., Bell, R. E., Duffy, O. B., and Fossen, H.: Reactivation of intrabasement structures during rifting: A case study from offshore southern Norway, J. Struct. Geol., 91, 54-73, 2016.

Phillips, T. B., Magee, C., Jackson, C. A.-L., and Bell, R. E.: Determining the three-dimensional geometry of a dike swarm and its impact on later rift geometry using seismic reflection data, geology, 46, 2, 119-122, 2018.

Piepjohn, K.: The Svalbardian-Ellesmerian deformation of the Old Red Sandstone and the pre-Devonian basement in NW Spitsbergen (Svalbard), in: New Perspectives on the Old Red Sandstone, edited by: Friend, P. F. and Williams, B. P. J., Geol. Soc. Spec. Publ., 180, 585-601, 2000.

Piepjohn, K., von Gosen, W., Läufer, A., McClelland, W. C., and Estrada, S.: Ellesmerian and Eurekan fault tectonics at the northern margin of Ellesmere Island (Canadian High Arctic), Z. Dt. Ges. Geowiss., 164, 81-105, 2013.

Piepjohn, K., Dallmann, W. K., and Elvevold, S.: The Lomfjorden Fault Zone in eastern Spitsbergen (Svalbard), in: CircumArctic Structural Events: Tectonic Evolution of the Arctic Margins and Trans-Arctic Links with Adjacent Orogens, edited by: Piepjohn, K., Strauss, J. V., Reinhardt, L., and McClelland, W. C., Geol. Soc. Am Spec. Pap., 541, 95-130, 2019.

Ramsay, J. G.: Interference Patterns Produced by the Superposition of Folds of Similar Type, J. Geol., 70, 466-481, 1962.

Rice, A. H. N.: Restoration of the External Caledonides, Finnmark, North Norway, in: New Perspectives on the Caledonides of Scandinavia and Related Areas, edited by: Corfu, F., Gasser, D., and Chew, D. M., Geol. Soc. Spec. Publ., 390, 271-299, 2014.

Roberts, D.: Tectonic Deformation in the Barents Sea Region of Varanger Peninsula, Finnmark, Norg. Geol. Unders. B., 282, 139, 1972.

Roberts, D. and Olovyanishshnikov, V.: Structural and tectonic development of the Timanide orogeny, in: The Neoproterozoic Timanide Orogen of Eastern Baltica, edited by: Gee, D. G. and Pease, V., Geol. Soc. Mem., 30, 47-57, 2004.

Roberts, D. and Onstott, T. C.: ${ }^{40} \mathrm{Ar} /{ }^{39} \mathrm{Ar}$ laser microprobe analyses and geochemistry of dolerite dykes from the Rybachi and Sredni Peninsulas, NW Kola, Russia, Nor. geol. unders. Special Publication, 7, 307-314, 1995.

Roberts, D. and Siedlecka, A.: Timanian orogenic deformation along the northeastern margin of Baltica, Northwest Russia and Northeast Norway, and Avalonian-Cadomian connections, Tectonophysics, 352, 169-184, 2002.

Roberts, D. and Williams, G. D.: Berggrunnskart Kjøllefjord 2236 IV, M $1: 50.000$, foreløpig utgave, Norges geologiske undersøkelse, Trondheim, Norway, 2013.

Roberts, D., Mitchell, J. G., and Andersen, T. B.: A post-Caledonian dyke from Magerøy North Norway: age and geochemistry, Norw. J. Geol., 71, 289-294, 1991.
Rosa, D., Majka, J., Thrane, K., and Guarnieri, P.: Evidence for Timanian-age basement rocks in North Greenland as documented through $\mathrm{U}-\mathrm{Pb}$ zircon dating of igneous xenoliths from the Midtkap volcanic centers, Precambrian Res., 275, 394-405, 2016.

Senger, K., Roy, S., Braathen, A., Buckley, S., Bælum, K., Gernigon, L., Mjelde, R., Noormets, R., Ogata, K., Olaussen, S., Planke, S., Ruud, B. O., and Tveranger, J.: Geometries of doleritic intrusions in central Spitsbergen, Svalbard: an integrated study of an onshore-offshore magmatic province with applications to $\mathrm{CO}_{2}$ sequestration, Norw. J. Geol., 93, 143-166, 2013.

Siedlecka, A.: Late Precambrian Stratigraphy and Structure of the North-Eastern Margin of the Fennoscandian Shield (East Finnmark - Timan Region), Norg. Geol. Unders. B., 316, 313-348, 1975.

Ziemniak, G., Majka, J., Manecki, M., Walczak, K., Jeanneret, P., Mazur, S. and Kosminska, K.: Early Devonian sinistral strikeslip in the Caledonian basement of Oscar II Land advocates for escape tectonics as a major mechanism for Svalbard terranes assembly, Geophys. Res. Abs., EGU General Assembly, May 3rd8th 2020, Vienna, Austria, 2020

Siedlecka, A. and Roberts, D.: Report from a visit to the Komi Branch of the Russian Academy of Sciences in Syktyvkar, Russia, and from fieldwork in the central Timans, August 1995, Norges Geol. Unders. Report, 95.149, 32 pp., 1995.

Siedlecka, A. and Siedlecki, S.: Some new aspects of the geology of Varanger peninsula (Northern Norway), Norg. Geol. Unders. B., 247, 288-306, 1967.

Siedlecka, A. and Siedlecki, S.: Late Precambrian sedimentary rocks of the Tanafjord-Varangerfjord region of Varanger Peninsula, Northern Norway, in: The Caledonian Geology of Northern Norway, edited by: Roberts, D. and Gustavson, M., Norg. Geol. Unders. B., 269, 246-294, 1971.

Smelror, M., Petrov, O. V., Larssen, G. B., and Werner, S. C.: Geological Atlas of the Barents Sea, Geological Survey of Norway, Trondheim, Norway, 2009.

Smyrak-Sikora, A., Osmundsen, P. T., Braathen, A., Ogata, K., Anell, I., Mulrooney, M. J., and Zuchuat, V: Architecture of growth basins in a tidally influenced, prodelta to delta-front setting: The Triassic succession of Kvalpynten, East Svalbard, Basin Res., 32, 959-988, 2020.

Stouge, S., Christiansen, J. L., and Holmer, L. E.: Lower Palaeozoic stratigraphy of Murchisonfjorden and Sparreneset, Nordaustlandet, Svalbard, Geogr. Ann. A, 93, 209-226, 2011.

Sturt, B. A., Pringle, I. R., and Ramsay, D. M.: The Finnmarkian phase of the Caledonian Orogeny, J. Geol., Soc. London, 135, 597-610, 1978.

Thiede, J., Pfirman, S., Schenke, H.-W., and Reil, W.: Bathymetry of Molloy Deep: Fram Strait Between Svalbard and Greenland, Mar. Geophys. Res., 12, 197-214, 1990.

Tonstad, S. A.: The Late Paleozoic development of the Ottar basin from seismic 3D interpretation, Master's Thesis, University of Troms $\varnothing$, Troms $\varnothing$, Norway, 135 pp., 2018.

Torsvik, T. H. and Trench, A.: The Ordovician history of the Iapetus Ocean in Britain: new palaeomagnetic constraints, J. Geol. Soc. London, 148, 423-425, 1991.

Torsvik, T. H., Burke, K., Steinberger, B., Webb, S. J., and Ashwal, L. D.: Diamond sampled by plumes from the core-mantle boundary, Nature Lett., 466, 352-355, 2010. 
Townsend, C.: Thrust transport directions and thrust sheet restoration in the Caledonides of Finnmark, North Norway, J. Struct. Geol., 9, 345-352, 1987.

Vernikovsky, V. A., Metelkin, D. V., Vernikovskaya, A. E., Matushkin, N. Yu., Lobkovsky, L. I., and Shipilov, E. V.: Early evolution stage of the arctic margins (Neoproterozoic-Paleozoic) and plate reconstructions, ICAM VI Proceedings, May 2011, Fairbanks, Alaska, USA, 265-285, 2011.

Von Gosen, W. and Piepjohn, K.: Polyphase Deformation in the Eastern Hornsund Area, Geologisches Jahrbuch, B91, 291-312, 2001.
Witt-Nilsson, P., Gee, D. G., and Hellman, F. J.: Tectonostratigraphy of the Caledonian Atomfjella Antiform of northern Ny Friesland, Svalbard, Norsk Geol. Tidsskr., 78, 67-80, 1998.

Worsley, D., Agdestein, T., Gjelberg, J. G., Kirkemo, K., Mørk, A., Nilsson, I., Olaussen, S., Steel, R. J., and Stemmerik, L.: The geological evolution of Bjørnøya, Arctic Norway: implications for the Barents Shelf, Norsk Geol. Tidsskr., 81, 195-234, 2001.

Ziegler, P. A.: Evolution of the Arctic-North Atlantic and the Western Tethys, AAPG Memoir. 43, 164-196, 1988. 